\title{
PRESENCIA DE UN CENTRO CEREMONIAL FORMATIVO EN LA CIRCUMPUNA DE ATACAMA
}

\author{
PRESENCE OF A FORMATIVE CEREMONIAL CENTER IN ATACAMA'S \\ CIRCUMPUNA
}

\author{
Lautaro Núñez, Isabel Cartajena ${ }^{2,3}$, Carlos Carrasco ${ }^{4}$, Patricio López M.2,3, \\ Patricio de Souza ${ }^{4}$, Francisco Rivera ${ }^{5}$ y Boris D. Santander 6
}

\begin{abstract}
... había una ceremonia de clausura, luego de que una delgada capa de relleno de montículo o arena fuera dispuesta sobre el piso, se procedía a sellar esta superficie, quemando madera y paja (Hastorf 2008a:9).
\end{abstract}

\begin{abstract}
En el presente trabajo se discuten las evidencias del sitio Tulán-54 con especial énfasis en el templete central. Este sitio es parte de un sistema de tres grandes asentamientos formativos tempranos sincrónicos (3450 a 2370 años cal. a.p.), dispuestos en el transecto Tulán, en un tramo de $15 \mathrm{~km}$ en el SE de la cuenca del salar de Atacama. Cada uno presenta funciones diferenciadas asociadas a la caza, pastoreo, recolecta y horticultura subsidiaria. En este contexto, el sitio Tulán-54 se perfila como el eje religioso con un marcado componente local orientado a los grupos que ocuparon la quebrada dentro de un contexto de redes macrorregionales. El templete no solo se caracteriza por su arquitectura monumental y los entierros de infantes, sino también por sus ofrendas, la incorporación de arte rupestre y por la reiteración de eventos rituales en su interior, cuyos restos lograron colmatar el templete en un lapso de ca. 200 años. La reiteración de eventos ceremoniales habría estado orientada a la cohesión social de grupos con una amplia movilidad que ocuparon recurrentemente los asentamientos de la quebrada Tulán, donde el comienzo de la desigualdad y las distintas formas productivas habrían sido conducidas por medio de la hegemonía ritual del liderazgo local.
\end{abstract}

Palabras claves: circumpuna, Fase Tilocalar, Formativo Temprano, templete, pastoralismo.

Archaeological evidence of the Tulán-54 site is discussed with a special emphasis on the central temple. Situated in the Tulán transect, which stretches over $15 \mathrm{~km}$ southeast of the Salar de Atacama basin, this site is part of a system of three large synchronous Early Formative settlements (3450 to $2370 \mathrm{BP}$ cal.). Each settlement presents different functions associated with hunting, herding, gathering and subsidiary horticulture. The Tulán-54 site emerges as a religious axis with a strong local component oriented to the groups who occupied the ravine within a context of macroregional networks. The temple is not only characterized by its monumental architecture and children's burials, but also by the funerary offerings, the incorporation of rock art as well as by the repetition of ritual events, the remains of which filled the temple in a span of 200 years. The reiteration of ceremonial events would have been oriented towards the social cohesion of groups with a wide mobility that recurrently occupied the settlements in the Tulán ravine, where the beginning of inequality and the different forms of production would have been driven through the ritual hegemony of local leadership.

Key words: Circumpuna, Tilocalar phase, Early Formative, temple, pastoralism.

La quebrada Tulán, al SE del salar de Atacama (Figura 1), ha sido estudiada exhaustivamente, observándose un complejo proceso de desarrollo local desde el Arcaico Tardío al Formativo Temprano, sustentado en un modelo de cazarecolección-pastoralismo de raigambre arcaica, con un relevante componente ritual. Las evidencias permitieron proponer la emergencia de una temprana complejidad formativa circumpuneña, en ambientes favorables con redes de interacción entre la costa y yunga oriental (Aschero 2006; Grosjean y Núñez 1994; Núñez et al. 2006a). Aquí se han documentado

1 Instituto de Arqueología y Antropología, San Pedro de Atacama, Universidad Católica del Norte, Calle Gustavo Le Paige No380, San Pedro de Atacama, Chile. lautaro.nunez@hotmail.com

2 Facultad de Ciencias Sociales, Departamento de Antropología, Universidad de Chile, Ignacio Carrera Pinto 1045, Ñuñoa, Chile. isabel.cartajena@uchile.cl; patriciolopezmendgmail.com

3 ARQMAR-Centro de Investigación en Arqueología Marítima del Pacífico Sur Oriental, Santiago, Chile.

4 Colegio de Arqueólogos A.G., Santiago, Chile. carrcag@gmail.com; desouza.herreros@ gmail.com

5 José Manuel Infante 14, Depto. 42, Providencia, Santiago. franchurivera@ gmail.com

6 Departamento de Antropología, Universidad Alberto Hurtado. Almirante Barroso \#10, Santiago, Chile. bsantander@uahurtado.cl

Recibido: enero 2016. Aceptado: junio 2016.

http://dx.doi.org/10.4067/S0717-73562017005000003. Publicado en línea: 23-marzo-2017. 


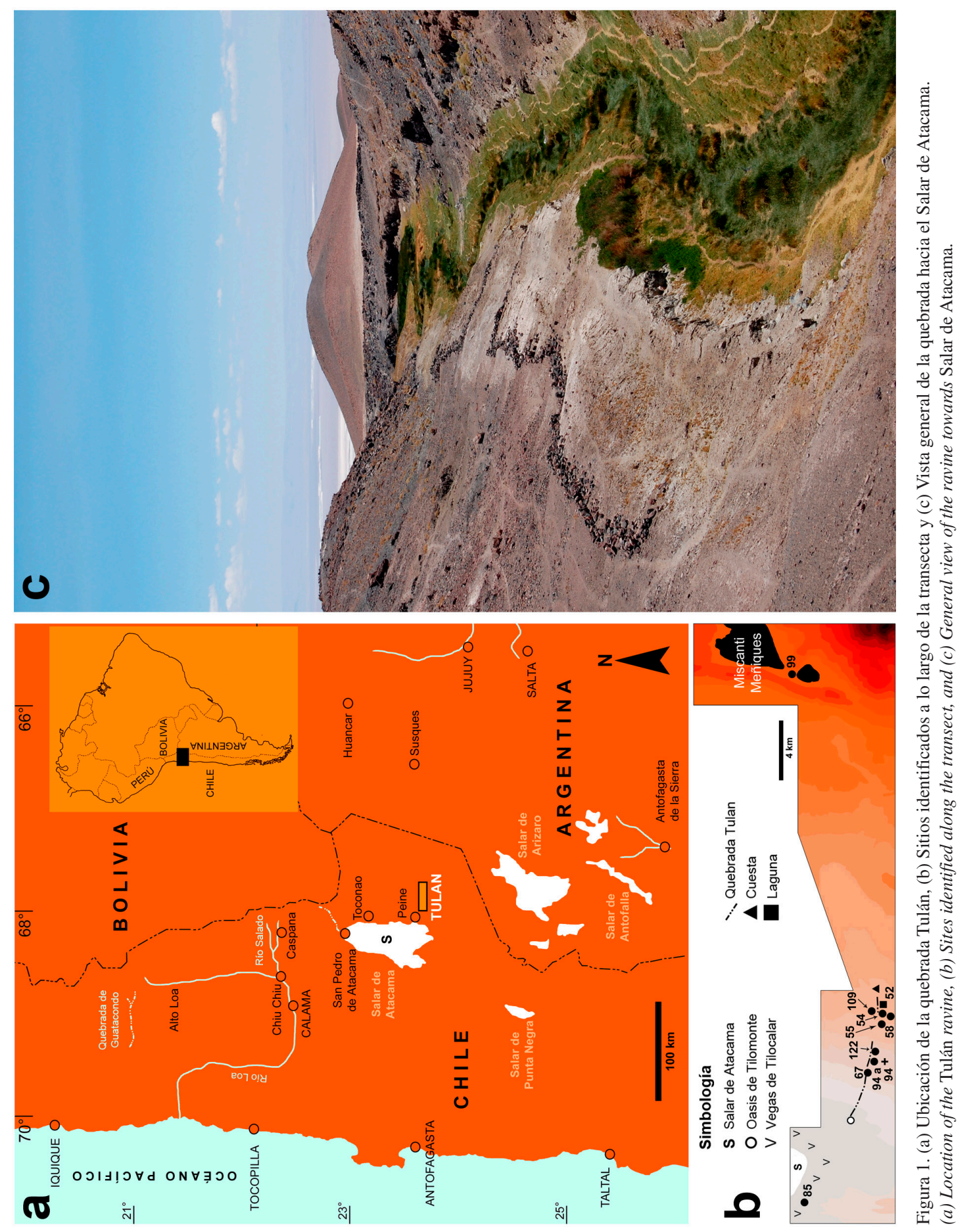


tres asentamientos formativos tempranos (ca. 33602370 años cal. a.p.) en un espacio alternado de 15 km: Tulán-54, 85 y 122, los que si bien en términos de diversidad y frecuencia de restos artefactuales y ecofactuales registran componentes similares, sus contextos materiales y arquitectónicos difieren notablemente en cuanto a su funcionalidad y monumentalidad.

Los tres asentamientos sincrónicos de la fase Tilocalar se encuentran además en espacios complementarios de corta distancia entre quebradas y oasis intermedios y las playas del salar (López 2010; López et al. 2013). En Tulán-122, junto al arroyo, se enfatiza el rol residencial, mientras que en el borde del salar el sitio Tulán-85 presenta más actividades productivas, en tanto que en Tulán-54 se marca un eje intermedio donde se acentúa un rol ceremonial y funerario. Esta modalidad ocupacional integrada entre pisos diferentes permitió la explotación ganadera, hortícola subsidiaria, recursos de vegas y prácticas de caza, con una organización político-religiosa común. En este contexto, en el presente artículo se abordan las evidencias actualizadas provenientes del templete que resaltan la importancia del sitio Tulán-54 como un centro ceremonial que articuló los grupos en un nivel local, aunque insertos en redes macrorregionales.

\section{La Fase Tilocalar}

La emergencia de los tres asentamientos formativos se ha identificado en el hábitat circunscrito de quebrada Tulán (Figura 1), donde los logros del Arcaico Tardío, correspondiente a la fase Puripica-Tulán (5290-4840 a 4430-4090 años cal. a.p.), transitaron a la fase intermedia Tarajne (3715-3560 a 3460-3200 años cal. a.p.) y luego a la fase Tilocalar del Formativo Temprano (3450-3080 a 2410-2370 años cal. a.p.). En esta última es donde se observa un progresivo grado de agregación social e intensificación acerca de los productos de caza y crianza de camélidos, sustentada en una economía mixta dominante (Núñez et al. 2006a), donde la explotación de los recursos locales provenientes de distintos microambientes fueron determinantes para explicar la ubicación de las ocupaciones: canteras, vertientes, arroyo estable, vegas forrajeras, vertientes en el salar, y vegetación interfluvial y arbórea de oasis de carácter estacional.
Los asentamientos de esta fase sugieren el desarrollo de un modelo de asentamientos complementarios entre sí, en un rango de 15 km entre las vegas del salar de Atacama y el nacimiento de la quebrada (2.300 a $3.000 \mathrm{msm})$. El sitio Tulán-85 (3480-3210 a 2410-2370 años cal. a.p.), ubicado en el borde del salar $(2.318 \mathrm{msm})$, presenta un montículo central de basuras de hasta 2,4 $\mathrm{m}$ de profundidad, resultante del descarte de diversas actividades de manufactura, procesamiento y consumo, acumuladas en un espacio abierto sin recintos asociados. Las únicas estructuras domésticas se excavaron en el sector SE con formas circulares y subcirculares aglomeradas, construidas en hilada simple de grandes lajas verticales, datadas al final de la fase, vinculadas a la preparación y consumo de alimento, incluyendo la producción de objetos perforados. En uno de sus recintos se registró un rasgo de lajas verticales en forma de cámara, que sirvió también de fogón, y en un rincón cercano, la inhumación de un infante con un collar de cuentas de mineral de cobre trenzado con pelo humano datado en 24702330 años cal. a.p. (Carrasco y de Souza 2009; Kalazich 2006). Si bien no se observan estructuras destinadas a actividades rituales, se registraron cinco infantes intercalados en la estratigrafía, sin ofrendas, salvo la presencia de un individuo con turbante y, en otro, una cuchara de cobre de mango corto, localizado sobre la muestra datada $(3140 \pm 70$ a $2500 \pm 40$ años a.p.).

El sitio Tulán-122 (3230-2960 a 2740-2460 años cal. a.p.) se encuentra en el borde SE del arroyo $(2.680 \mathrm{msm})$. A diferencia del anterior, se compone de una profusión de recintos y estructuras habitacionales aisladas o aglutinadas, con actividades domésticas $(\mathrm{n}=154)$. Presenta tres conjuntos arquitectónicos centrales con escasos depósitos de basuras, con evidencias consistentes con un patrón de explotación móvil, asociado a la crianza de camélidos, con cacerías y recolección, de acuerdo con la presencia de taxones silvestres, fauna menor, puntas de proyectil y abundante registro vegetal de la localidad. En este asentamiento no se han registrado evidencias de ritualidad, aunque se han observado nichos aislados adosados a los muros iguales a los registrados en el templete de Tulán-54 (McRostie 2014).

Finalmente, el sitio Tulán-54 ubicado a $~ 3 \mathrm{~km}$ aguas arriba del anterior, cercano al nacimiento del arroyo (2.952 msm), presenta varios sectores de acumulación que muestran una compleja organización 
del espacio, con depósitos y fogones expuestos, y que son detallados más adelante.

La subsistencia durante la fase Tilocalar se sustentó principalmente en los productos obtenidos de camélidos cuyos restos se encuentran en abundancia en los tres sitios (Cartajena 2009). Los vegetales incluyeron raíces y frutos locales como chañar, cactáceas (kume) y el uso de algunos cultígenos en baja frecuencia: ají, quinua, calabaza, zapallo, oca y maíz (Núñez, McRostie y Cartajena 2009). La presencia de mineral de cobre y martillos remite a actividades extractivas que estarían relacionadas a una altísima producción excedentaria de cuentas asociadas a miles de microperforadores (Núñez et al. 2007), mientras que la presencia de objetos de oro, plomo y cobre darían cuenta, a su vez, de una producción minero-metalúrgica. La cerámica dominante corresponde al grupo los Morros, registrada en todos los asentamientos (Sinclaire et al. 1998; Uribe 2004). Por su parte, la industria lítica se orientó principalmente a la obtención de productos de camélidos (cuchillos, raspadores, raederas), actividades cinegéticas denotadas por puntas de proyectil (puntas pedunculadas y lanceoladas), producción de cuentas (microperforadores) y tientos de cuero, además de actividades de molienda (manos y metates).

En relación con la presencia de bienes obtenidos mediante el intercambio, los objetos registrados en los tres sitios remiten a la obtención de bienes exóticos utilizados para la elaboración de artesanías como cuentas confeccionadas de conchas provenientes del Pacífico como del noroeste argentino presentes en los sitios Tulán-54 y 85 (Soto 2009, 2010). Además, se encuentran elementos foráneos procedentes también del oriente como cebil, pipas, cerámica intrusiva cordelada, digitada e imbricada, y posiblemente el escaso maíz que se encuentra al interior del templete y que se habría utilizado como parafernalia o para consumo en actividades rituales dentro de este recinto. Finalmente, se registran aquellos depositados como ofrendas junto a los infantes como conchas (Strophocheulus oblongus) enteras que contenían pigmentos. En sitios contemporáneos y cercanos a Tulán-54 también se recuperaron objetos que fueron depositados como ofrendas que presentan una amplia distribución, como los tocados de hueso dentados identificados en los turbantes formativos de los valles bajos, litoral aledaño y la cuenca del Loa Medio (Núñez et al. 2006a, 2006b; Núñez, Cartajena, Carrasco et al. 2006).
La imbricación no solo de los tres grandes asentamientos, sino también de los numerosos sitios con arte rupestre identificados en el transecto Tulán (Tulán-60 y 109, entre otros), más la presencia de ocupaciones bajo roca (Tulán-55), canteras, campamentos de tareas, entre otros, sugieren que durante la Fase Tilocalar se consolidó un foco de notables transformaciones, dando lugar a un modelo de habitar segmentado e interconectado, articulado desde el centro ceremonial Tulán-54, consolidándose como un eje político y religioso a nivel local, pero enmarcado en una amplia red de interacciones.

\section{El Templete Tulán}

El sitio Tulán-54 correspondiente al centro ceremonial, cubre ca. $2.800 \mathrm{~m}^{2}$ (Figura 2). En la superficie se distinguen restos culturales, orgánicos y fogones con ceniza, mientras que en la periferia más extendida se registran talleres de reducción de láminas de toba y microlascas silíceas, estructuras superficiales y áreas de combustión que incrementan el total del espacio ocupado a ca. $8.000 \mathrm{~m}^{2}$, de los cuales las excavaciones del templete han decapado hasta la fecha $98 \mathrm{~m}^{2}$ con depósitos que alcanzan una profundidad máxima de ca. $2 \mathrm{~m}$ sobre el piso original.

Inicialmente se expusieron los cabezales del muro perimetral de una estructura semiovalada, que contiene un piso de $85-90 \mathrm{~m}^{2}$ dividido por recintos interiores. El proceso de construcción siguió un patrón secuencial, en el cual primero se socavó y niveló el piso, levantándose el muro perimetral, incrustando los bloques verticales en el subsuelo estéril y compacto. Para sustentarlo se acumularon rocas de apoyo en su exterior, mientras que en el interior se observan en la vertical dos niveles constructivos (Figura 3). El inferior, con grandes bloques o machones de tendencia megalítica, dejando nichos entre dos jambas (algunas pulimentadas) que sostienen dinteles. Encima se levantó el segundo nivel con bloques planiformes, dispuestos horizontalmente con cuñas. Se relevaron posteriormente en su interior seis recintos con muros simples de lajas más delgadas levantados postmuro periférico, orientados hacia una estructura central de tendencia oval, sobre el piso original y apoyados lateralmente en el muro perimetral (Figuras 3 y 4).

El ingreso al templete desciende por una rampa estrecha ubicada al este. En el piso se excavaron 


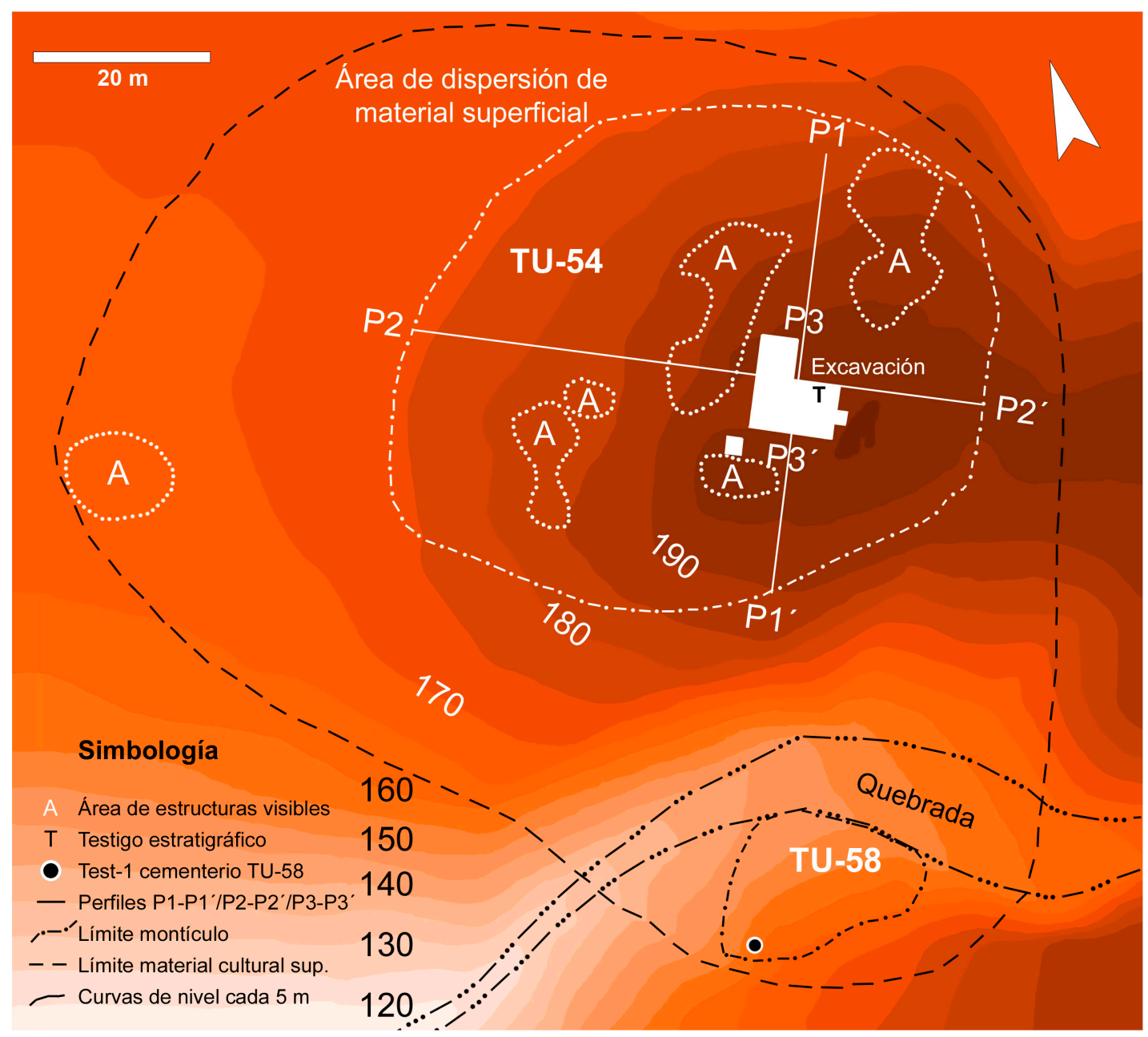

Figura 2. Planta general del sitio Tulán-54.

General ground plan of Tulán-54 site.

27 inhumaciones de infantes en fosos, junto al muro perimetral y al interior de los recintos e incluso al pie de bloques con diseños rupestres. En la estructura del centro (Figura 4F) se ubicaron dos infantes sobre un socavado semicircular, con ofrendas de prestigio: láminas de oro, cubilete lítico grabado y collar de lapidaria, entre otros (Figura 5a-d). Los restantes entierros también se disponen en fosos acondicionados con lajas y ofrendas sofisticadas, salvo en tres casos sin objetos asociados (Núñez et al. 2006a, 2006b). En los alrededores de las inhumaciones y en cada recinto se localizaron fogones circulares en cubeta, demarcados con fragmentos de implementos de molienda. Otros rasgos dan cuenta de "cajitas" de lajas, fosos vacíos tapados con lápidas, metates completos y fragmentados, fosos (coveros o pagapu) que contienen punzones de hueso, láminas de toba, restos triturados de mineral de cobre, un martillo con surco central, además de un gran marán de molienda acinturado con partículas de cobre adherido. Llama la atención algunos bloques grabados en el muro perimetral con motivos zoomorfos, antropomorfos e incisiones lineales, además de una pictografía con camélidos naturalistas y algunos segmentos del muro con pigmento rojo (Figura 6a-b).

De acuerdo con las dataciones obtenidas en los diversos sectores y al conjunto de evidencias artefactuales y contextuales, es posible proponer tres subfases para el sitio Tulán-54 (Figuras 7-9). La Subfase I corresponde a los inicios de ocupación, documentada en el exterior del templete con 


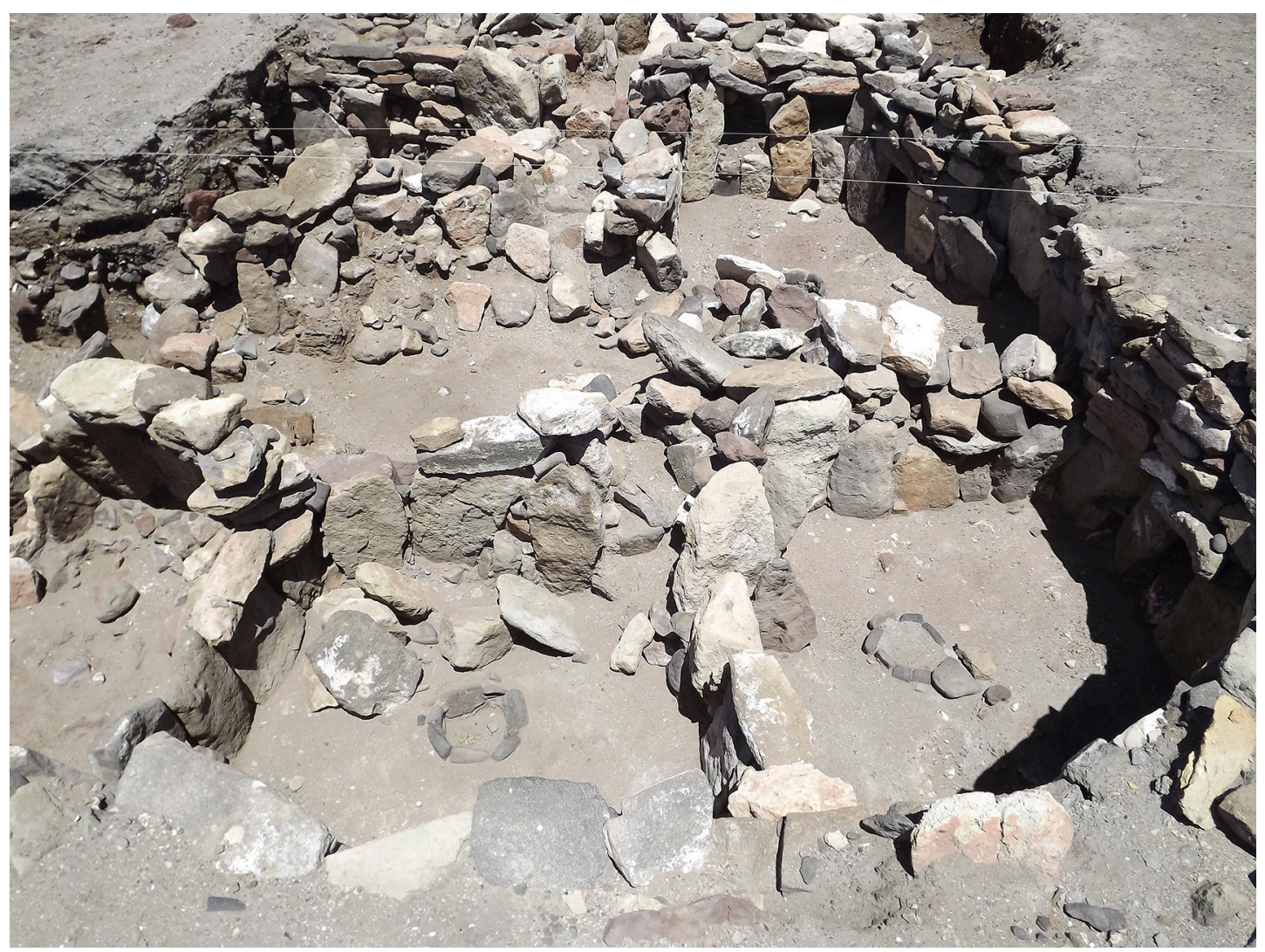

Figura 3. Vista parcial del Templete de Tulán-54.

Partial view of the ceremonial structure at Tulán-54.

anterioridad a su construcción. Las dataciones fluctúan desde 3360-2950 y 3170-2930 años cal. a.p. y provienen de depósitos de residuos sin estructuras, caracterizados por la superposición horizontal de residuos con abundantes restos orgánicos y fogones intercalados, formados previos a la construcción del templete (Núñez et al. 2006a, 2006b; Núñez, Cartajena y Carrasco 2011).

Durante la Subfase II se construyó el templete y la estructura ceremonial menor, una vez que la ocupación cubrió buena parte del espacio periférico, interviniéndose ahora el núcleo del sitio, y en su interior se efectuaron las inhumaciones de infantes (3050-2770 a 2870-2740 años cal. a.p.). La compleja estratigrafía intratemplete presenta tres unidades depositacionales diferenciadas. $\mathrm{Al}$ centro se formó un montículo constituido por una sucesión de microestratos laminados con fogones lenticulares limpios, arena eólica y residuos orgánicos finos. La notable escasez de material cultural y restos óseos sugiere que se alternaron frecuentes quemas rituales de baja intensidad, distintas a los fogones estructurados y en cubetas localizados en los pisos de los recintos laterales. Contrariamente, las estructuras adyacentes al muro perimetral se caracterizan por estratos continuos y espesos, con abundantes restos artefactuales y ecofactuales, intercalados por fogones y lentes extendidos de ceniza. La colmatación tanto del piso como de las estructuras interiores habría sucedido a lo largo de ca. 200 años por el descarte continuo de restos derivados de actividades redundantes al interior del templete (Figuras 8 y 9).

La Subfase III se corresponde con los cambios estratigráficos y arquitectónicos detectados al final de la secuencia del templete. Se extendería desde 2870-2740 hasta 2410-2370 años cal. a.p., momento en que cesan las actividades (Núñez, Cartajena y Carrasco 2011). Estos depósitos se conforman por una frecuente superposición de fogones menos extensos y lentes de ceniza, en una matriz disgregada de arena eólica y bloques 


\section{$\begin{array}{llllllllll}\text { I } & \text { H } & \text { G } & \text { F } & \text { E } & \text { D } & \text { C } & \text { B } & \text { A } & \text { B }^{\prime}\end{array}$}

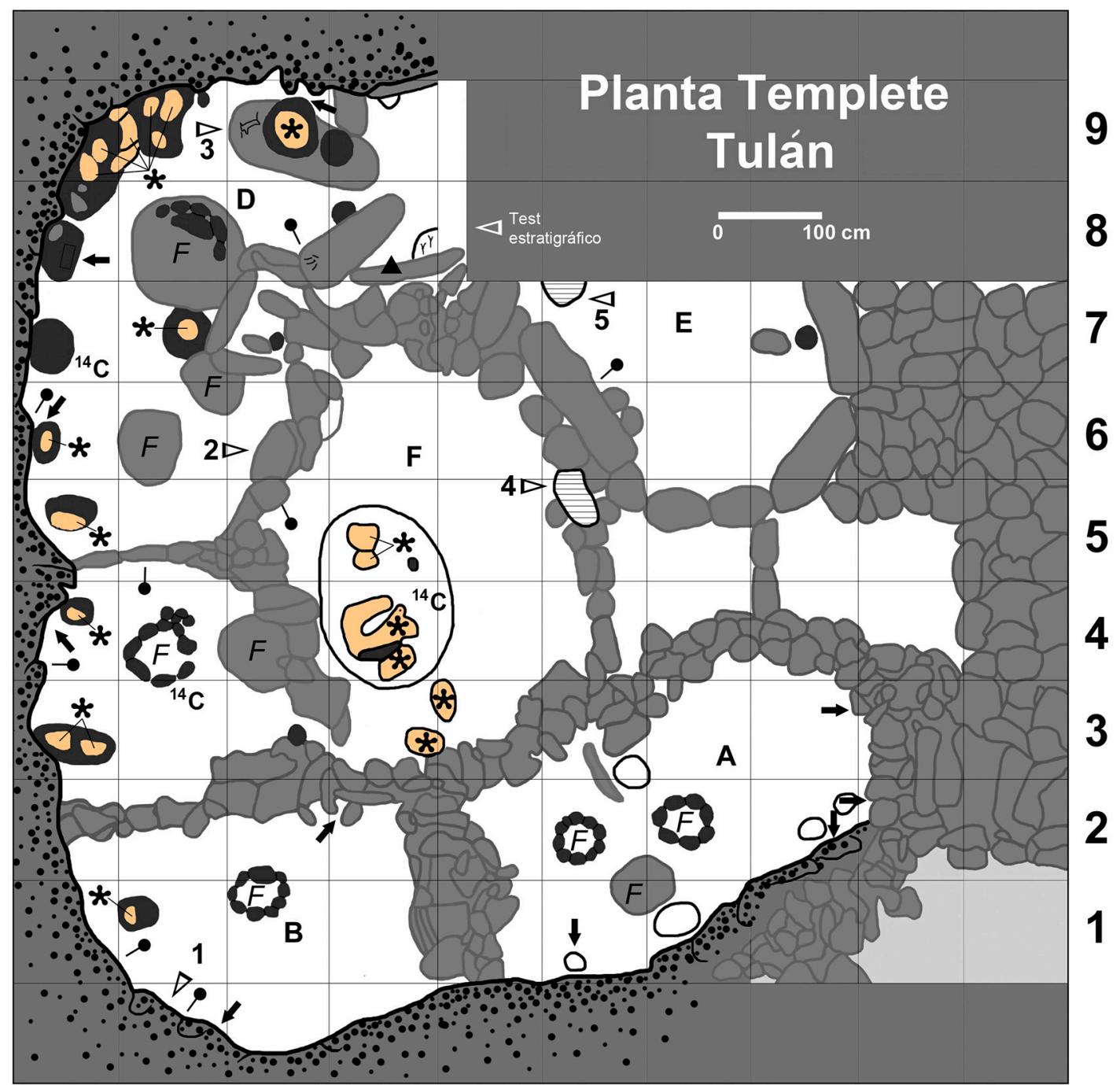

\section{Simbología}
A, B, C, D, E y F: Estructuras
F: Fogones estructurados y abiertos
$\triangleright$ : Petroglifos en estructuras $N^{\circ} s 1,2$ y 3

: Incisiones en estructuras

$\Rightarrow$ : Nichos en muro perimetral

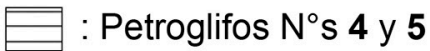

\& : Lápida sobre neonato en foso

$\Delta$ : Pintura roja (Estilo Confluencia)

Figura 4. Planta del templete del sitio Tulán-54.

Plan of the ceremonial structure of Tulán-54 site.

abatidos desde los cabezales de muros, con escaso registro de restos orgánicos y culturales, incluyendo sedimentos erosionados por el efecto de deflación superficial. Los eventos tardíos de la tercera unidad estratigráfica cubrieron completamente las estructuras del templete (Figuras 8 y 9). 

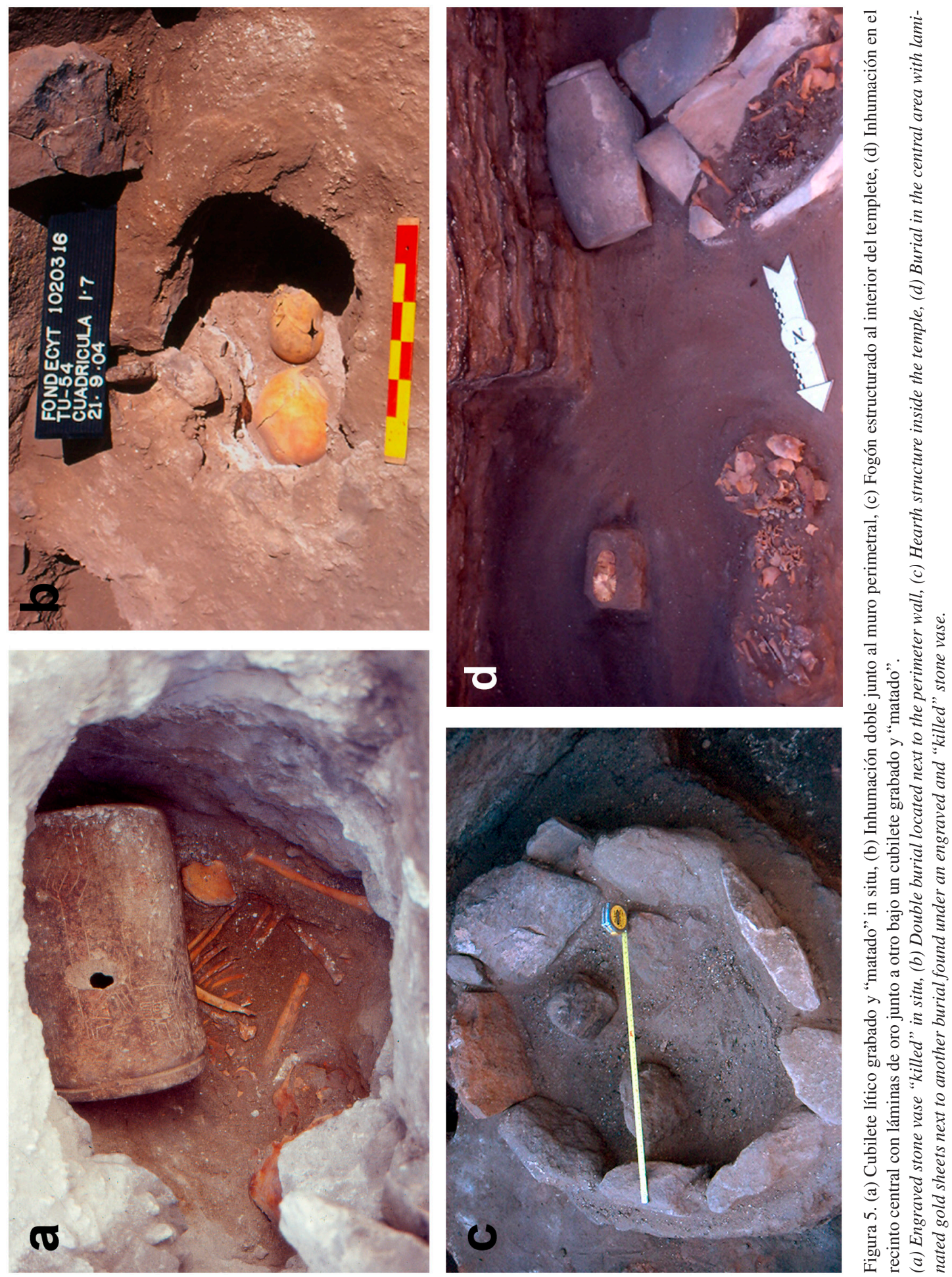

\section{(1)}

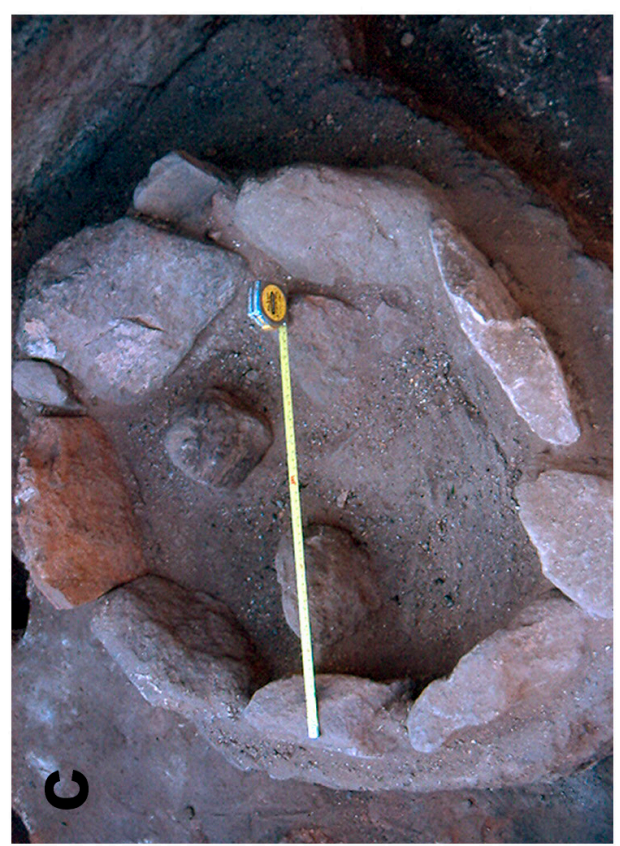

它氞焉 

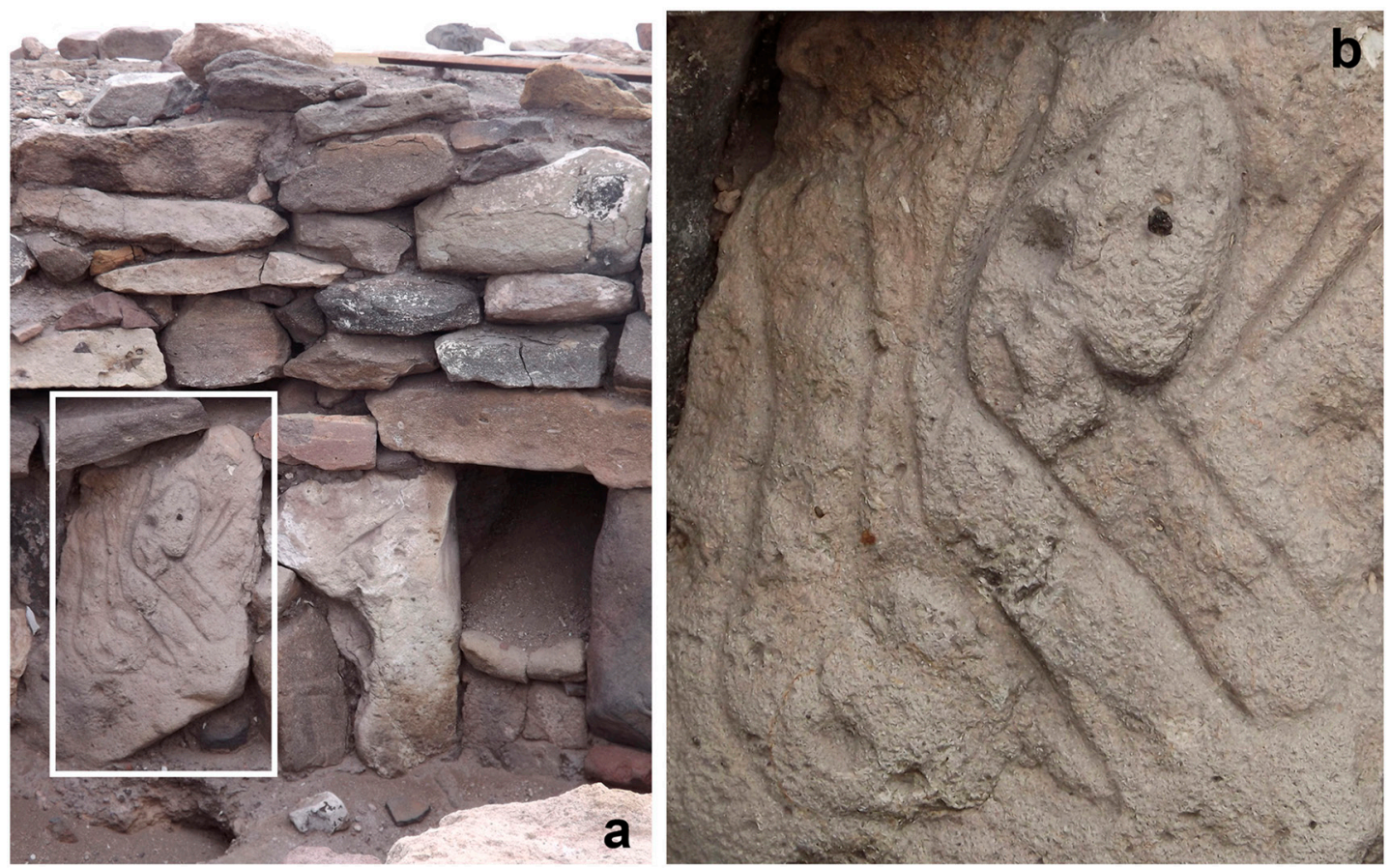

Figura 6. (a) Vista general de grabado con cabeza de camélido, (b) Detalle de grabado de camélido con incisiones al interior del templete.

(a) General view of the engraved head of a camelid, (b) Detail of engravings of a camelid with incisions inside the temple.

\section{Principales Indicadores Culturales}

\section{La industria lítica}

De una muestra de 12.259 instrumentos líticos clasificados procedentes de Tulán-54, los más frecuentes corresponden a microperforadores, cuchillos formales y expeditivos, puntas de proyectil pedunculadas, raspadores, láminas multifuncionales, preformas y núcleos (Figura 10). Los artefactos fueron elaborados en basalto, sílice, obsidiana, andesita, felsita y toba, esta última proveniente de canteras distantes a no más de $5 \mathrm{~km}$ del sitio. Los instrumentos más abundantes son los microperforadores $(67 \%$ del total), la mayoría de rocas silíceas. Se registraron núcleos pequeños de rocas silíceas, unidireccionales o bipolares, relacionados con la extracción de matrices para los microperforadores. A su vez, los perforadores se asocian con el proceso de manufactura de cuentas y pendientes para collares, confeccionadas sobre materias primas cupríferas, líticas y orgánicas.

Son frecuentes las puntas de proyectil, mayoritariamente pedunculadas $(75 \%)$, asociadas a lanceoladas y triangulares menos frecuentes de tradición arcaica. Suelen estar confeccionadas sobre obsidiana $(68,2 \%)$, aunque también se observan ejemplares en basalto, rocas silíceas y andesita. $\mathrm{La}$ amplia mayoría correspondería a puntas de flechas, con escasos ejemplares atribuibles a lanzas o a dardos de estólica (de Souza 2011).

Se registraron, además, cuchillos, raspadores, raederas e instrumentos multifuncionales, muchos sobre láminas (67\%), preferentemente en toba local, escasamente modificados, con retoque marginal en los bordes activos. La presencia de lascas provistas de filos expeditivos con adherencia de fibras sugiere labores de esquila en camélidos silvestres y domésticos. Se registraron, además, abundantes manos y metates, relacionados con intensas labores de molienda de alimentos.

Se desprende que los depósitos intratemplete se caracterizan por un amplio rango de categorías líticas. Incluyen instrumentos para labores extractivas y de procesamiento habituales en sitios habitacionales, las que adquieren aquí una connotación ceremonial a juzgar por las prácticas reiteradas de faenamiento de camélidos y comidas ritualizadas. 
OxCal v4.2.4 Bronk Ramsey (2013); r.5 SHCal13 atmospheric curve (Hogg et al 2013)

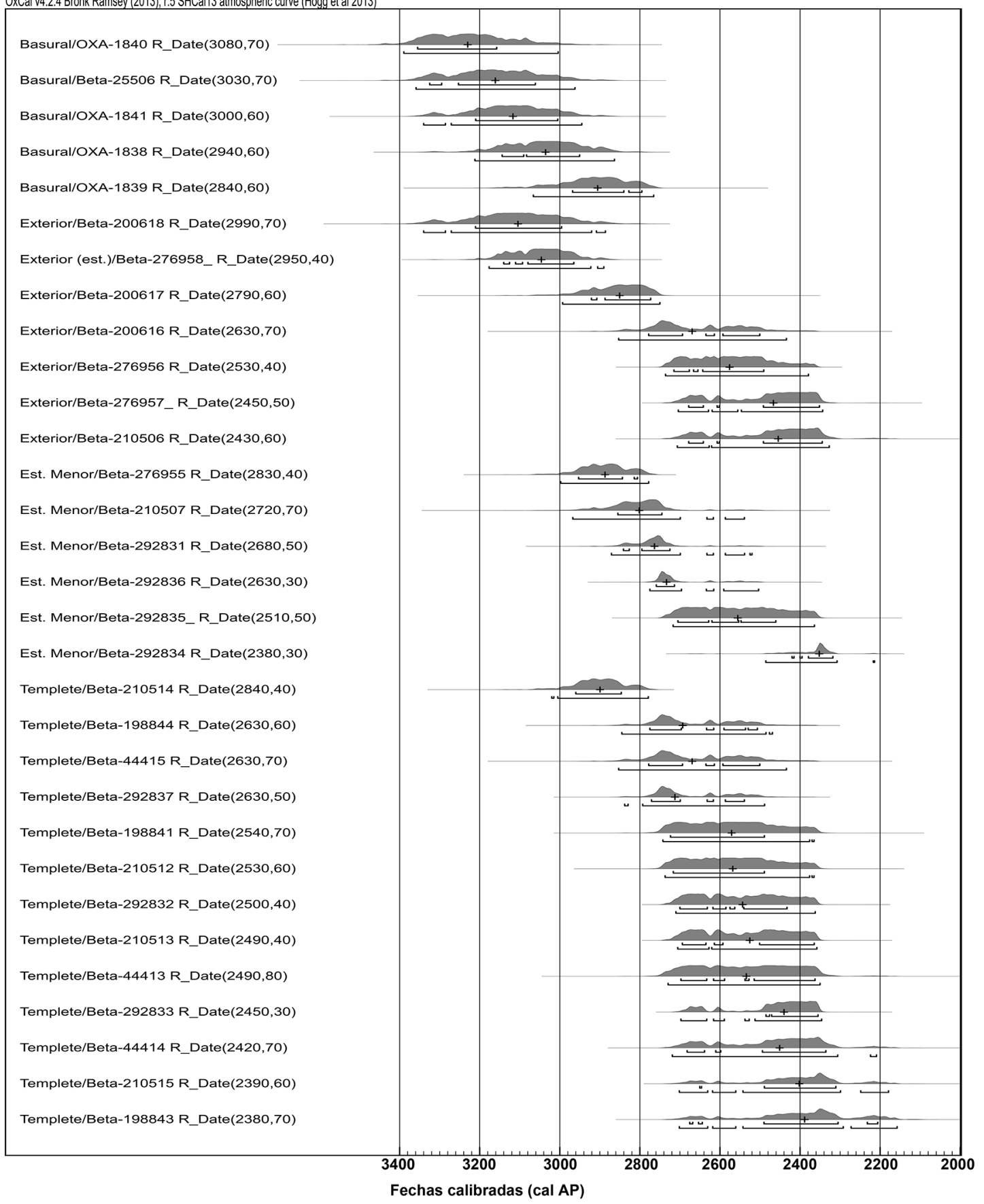

Figura 7. Dataciones calibradas obtenidas de los diferentes sectores del sitio Tulán-54: extratemplete (basural, estructura exterior y áreas exteriores), estructura ceremonial menor y del templete (tomadas de Hedges et al. 1989; Núñez 1992; Núñez et al. 2005; Núñez, Cartajena, Carrasco et al. 2011).

Calibrated dates of the different sectors of the Tulán-54 site: outside of the ceremonial structure (midden, exterior structure and external areas), inside the minor ceremonial structure and inside of the central ceremonial structure (taken from Hedges et al. 1989; Núñez 1992; Núñez et al. 2005; Núñez, Cartajena, Carrasco et al. 2011). 


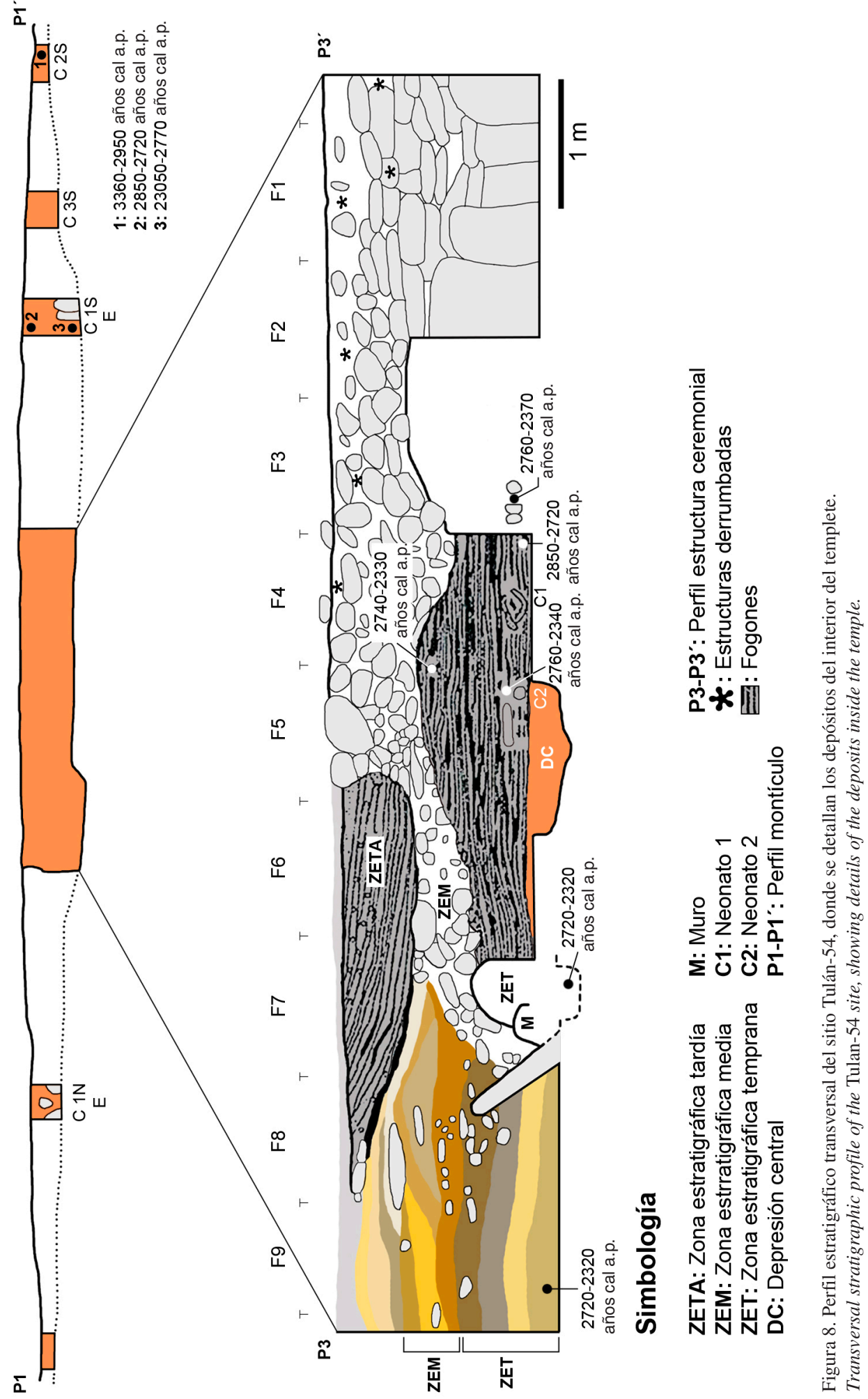




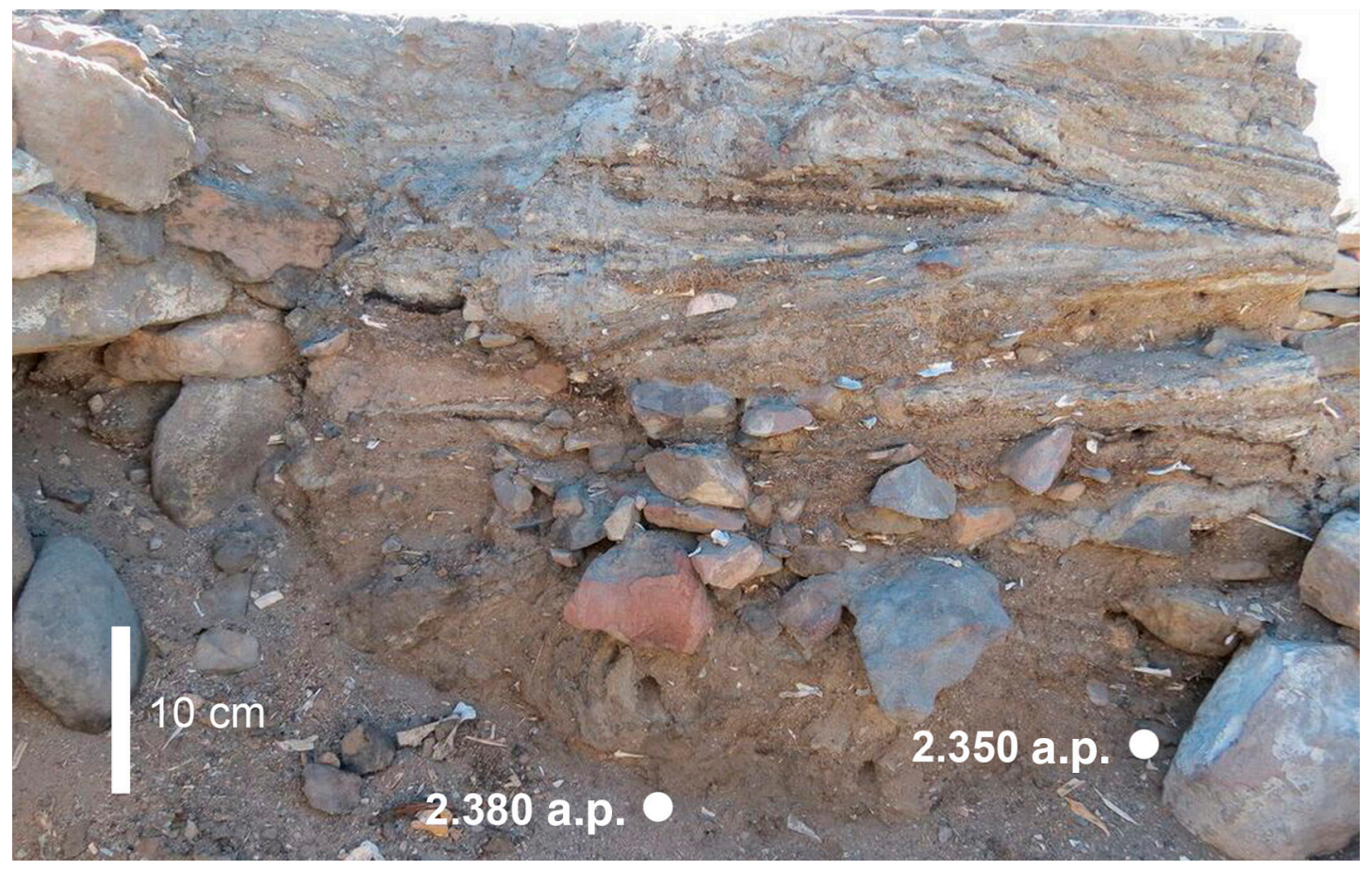

Figura 9. Perfil estratigráfico del interior del templete correspondiente a las cuadrículas F9 y F8 con ubicación de muestras fechadas. Stratigraphic profile of the interior of the central ceremonial structure corresponding to grids F8 and F9 indicating the location of the dated samples.

\section{La manufactura cerámica}

La mayor parte del conjunto cerámico recuperado del interior del templete corresponde a Los Morros, caracterizada por antiplásticos gruesos, propios del Formativo Temprano en el Loa Superior y Medio, los oasis del salar de Atacama y la vertiente circumpuneña (Sinclaire et al. 1998; Uribe 2006). Se trata de un patrón cerámico temprano, con una amplia distribución, caracterizada por sus atributos de pasta, bordes en coma, ausencia de asas, bases convexas, cuerpos esféricos, escasos jarros, decoración modelada, incisa, grabada, corrugada e impresiones de uña (Ayala y Uribe 2003; Benavente 1982; Fernández 1988-1989; García 1998; González y Westfall 2010; Tarragó 1989; Thomas et al. 1995; Ventura 1999). La cerámica presenta una alta frecuencia (según se desprende del total de fragmentos recuperados solo de un bloque de 1 $\mathrm{m}^{2}$, correspondiente a 1.939 fragmentos), en donde los más representados pertenecen al grupo Los Morros B1 (LMB1 49\%), seguido de Los Morros A (LMA 45\%), y Los Morros B2 (LMB2 4\%; Kalazich 2006) (Figura 11a-b).
Se registró además un bajo porcentaje de cerámica tipo San Pedro Negro Pulido en los estratos superiores y fragmentos de cuerpo de vasijas probablemente restringidas, de paredes delgadas con superficie pulida exterior café, con ligeras manchas más oscuras y brillo notable. Su asignación cultural podría corresponder al tipo Séquitor (San Pedro de Atacama), no obstante también podría afiliarse con componentes trasandinos (Varela 2011).

La cerámica se registra en toda la secuencia, sin embargo, solo en ocho de las inhumaciones de los infantes se documentaron fragmentos ofrendados, de los cuales, uno fue retomado, es decir, no eran aún objetos de ofrendas funerarias (Núñez et al. 2006a, 2006b). La alta representación de cerámica en el templete como los bajos índices de reparación sugieren un uso común asociado a la productividad local (Kalazich 2006). La frecuencia de vasijas para la preparación, consumo y servicio de comidas y bebidas sugieren actos redundantes durante toda la ocupación. La presencia de fragmentos de pipas tubulares y tiestos intrusivos cordelados, unguiculados e imbricados permiten establecer conexiones con las tierras bajas del noroeste 

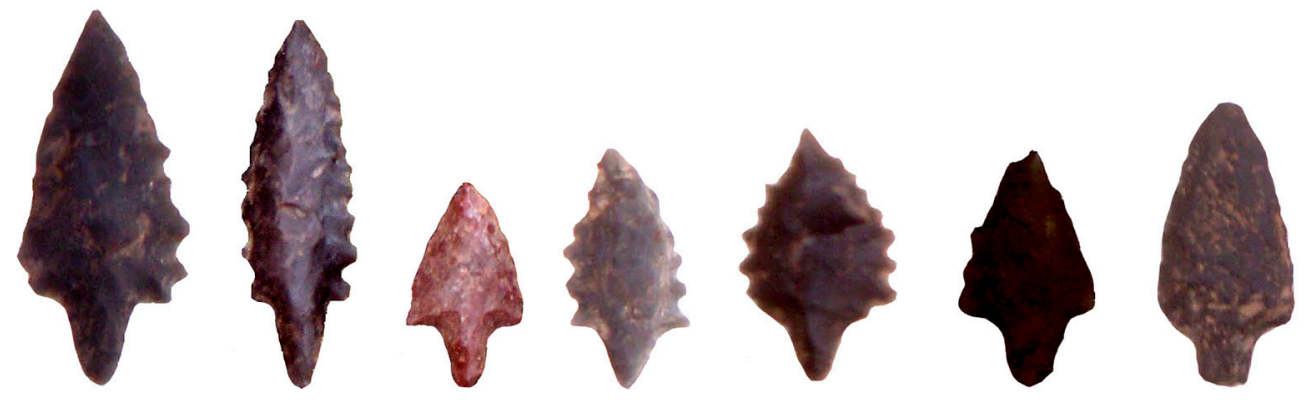

a
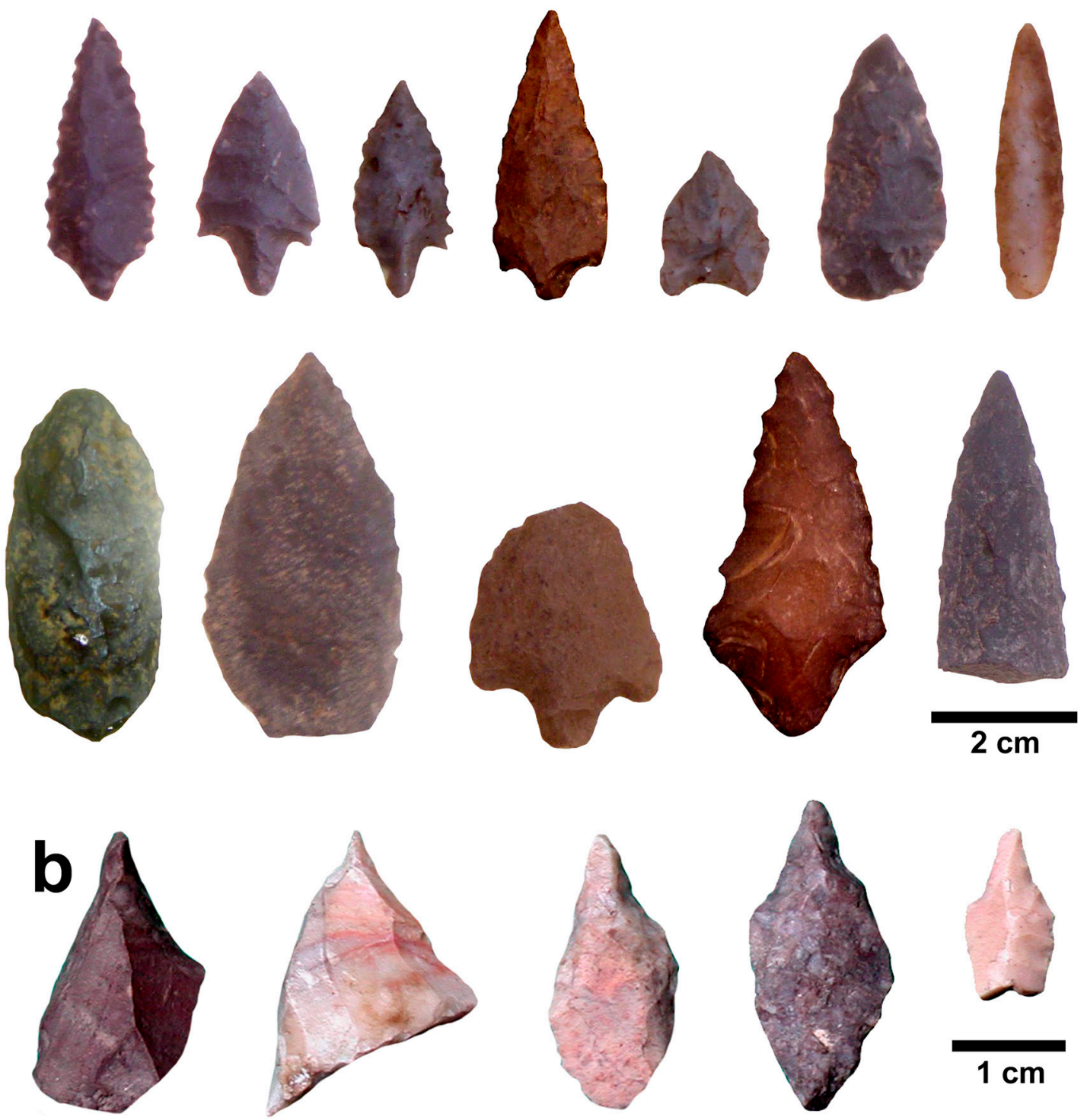

Figura 10. (a) Puntas de proyectil registradas en el sitio Tulán-54, (b) Microperforadores recuperados del sitio Tulán-54 (fotografías facilitadas por P. De Souza).

(a) Projectile points recovered at the site Tulán-54, (b) Microdrills recovered at the site Tulán-54 (Photos provided by Patricio de Souza). 


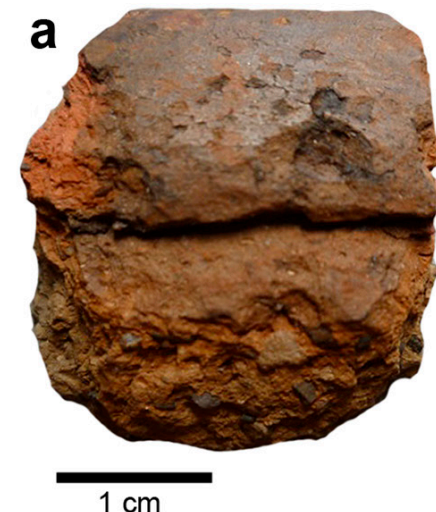

$1 \mathrm{~cm}$

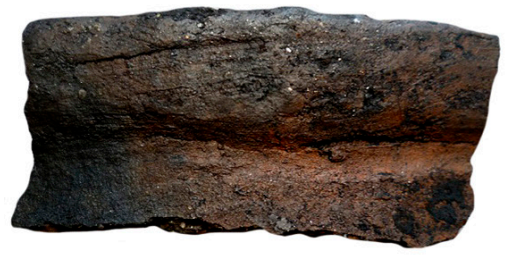

$1 \mathrm{~cm}$
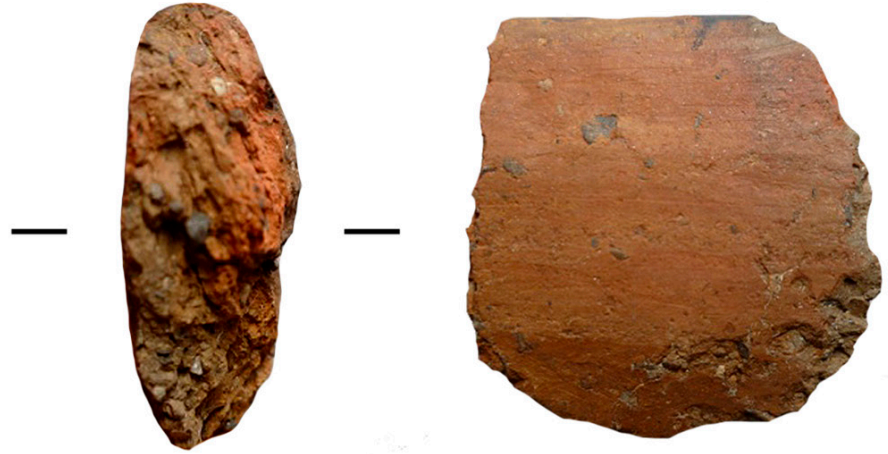

b
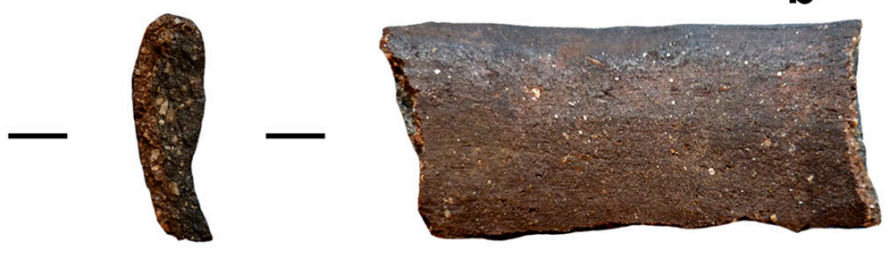

Figura 11. (a) LMA, fragmento de borde aparentemente de vasija no restringida (110 mm de diámetro de boca aproximadamente). Labio convexo con reborde anular por el exterior de $14 \mathrm{~mm}$ de ancho. A la izquierda superficie exterior, al centro superficie interior y a la derecha sección transversal (tomado de Varela 2011), (b) LMA, fragmento de borde, de vasija aparentemente no restringida (220 mm de diámetro de boca), seguramente una olla a juzgar por el tizne adherido en el exterior. El borde presenta un típico engrosamiento exterior. De izquierda a derecha: superficie exterior, interior y sección transversal (tomado de Varela 2011). (a) LMA, rim sherd apparently from an unrestricted vessel, of approximately $110 \mathrm{~mm}$ of orifice diameter. Convex lip with exterior annular rim of $14 \mathrm{~mm}$ of width. View of the outer sherd wall (left), of the inner sherd wall (center) and of the transverse cross section (right) (taken from Varela 2011), (b) LMA rim sherd of an apparently unrestricted vessel (220 mm orifice diameter), probably a pot judging from the soot adhering on the outside wall. The rim presents a typical exterior thickness. From left to right: outer sherd wall, interior sherd wall and transverse cross section (taken from Varela 2011).

argentino, relacionadas con el temprano tráfico de cebil (cf. Anadenanthera sp.) identificado en el templete (Kalazich 2006; McRostie 2014; Núñez, McRostie et al. 2009).

Para contrastar las dataciones $\mathrm{C}^{14}$ con la secuencia alfarera se lograron seis muestras para análisis de termoluminiscencia (UCTL N ${ }^{\circ} 2200$ a 2005). Los resultados en este mismo orden se fijaron en el rango de $2485 \pm 200$ a $2535 \pm 220$ años a.p. confirmando su pertenencia el periodo Formativo Temprano por un lado y por otro explicita la contemporaneidad de los tipos segregados (Román 2011).

\section{Restos arqueofaunísticos}

El total de evidencias procedentes de tres cuadrículas al interior del templete de los recintos
B, C y D permitieron recuperar 48.370 fragmentos, de estos, 4.810 (10\%) fueron identificados anatómicamente y el restante $90 \%$ corresponde a categorías generales: fragmentos de huesos largos, planos y mínimos (Calas 2007; Cartajena 2003). La mayoría del conjunto corresponde a restos de camélidos, y solo 3.130 pertenecen a fauna menor compuesta por roedores (90\%), mayoritariamente chinchíllidos (Lagidium viscazia, Chinchilla brevicaudata), cholulos (Ctenomys sp.) y Phyllotis sp. Las aves corresponden al restante $10 \%$, registrándose paseriformes, tortolitas (Metriopelia sp.) y parinas (Phoenicopteridae) (Calas 2007; Labarca 2005).

Dentro del grupo de los camélidos se determinó a nivel osteométrico la presencia de dos especies silvestres (Vicugna vicugna y Lama guanicoe) y una doméstica (Lama glama) (Figura 12a). En el rango de camélidos más grandes (guanaco/llama) 


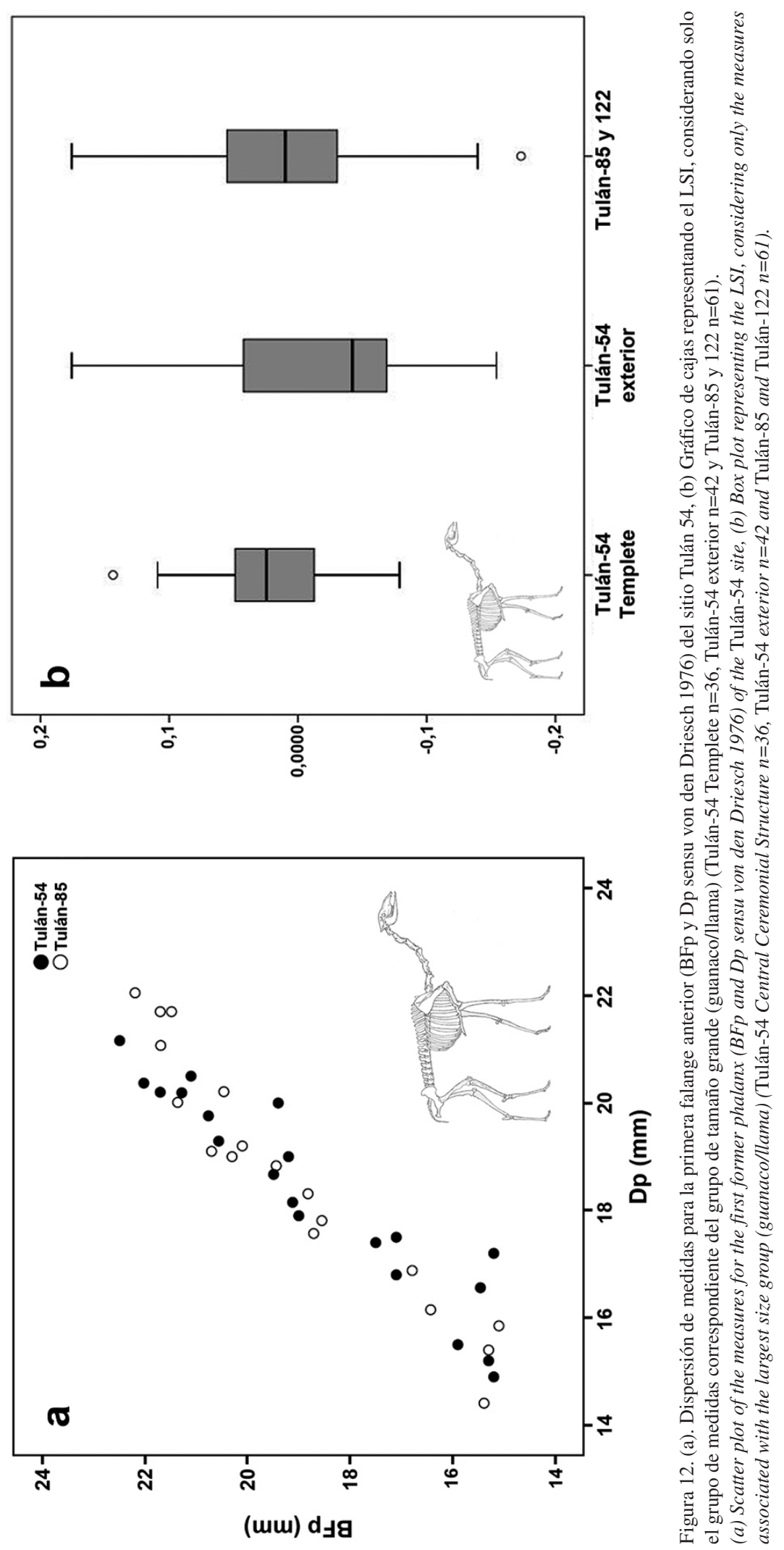


presenta una mayor dispersión; no obstante, al comparar las medidas del grupo de tamaño grande con restos provenientes del exterior del templete y de los sitios contemporáneos (Tulán-85 y 122), se observa que la mediana es levemente mayor pero la dispersión es menor (Figura 12b). Lo anterior podría denotar la selección de animales para actividades rituales, lo que sumado a la representación de vicuñas sugiere aun una marcada orientación hacia la caza.

Los análisis de correlación sugieren grandes similitudes en la representación de unidades anatómicas, no solo a nivel temporal (zonas estratigráficas) sino espacial entre los recintos (Calas 2007; Cartajena 2003). El perfil etario al interior del templete muestra una representación mayor de individuos subadultos (no fusionados) que en el exterior, alcanzando casi $35 \%$ en promedio al ser considerado en términos de \% MNE (Calas 2007; Cartajena et al. 2007). La mayoría se encuentra en el rango de 2 años a 9 meses, no obstante, se advierte un porcentaje constante de neonatos en promedio en torno al $10-20 \%$ del porcentaje del conjunto de los subadultos.

La representación de las unidades anatómicas recuperadas a lo largo de la ocupación como en los diferentes recintos presenta grandes similitudes. $\mathrm{Al}$ considerarlos en conjunto se observa que la cintura escapular alcanza una alta representación, mientras que los miembros superiores y medios se encuentran representados minoritariamente, en contraposición a una alta presencia del autopodio, especialmente de los huesos cortos (calcáneos y astrágalos), metapodios y falanges. Cráneo, mandíbula e hioides alcanzan una representación media, mientras que algunos segmentos vertebrales se encuentran bien representados (cervical y lumbar) (Figura 13). Los resultados obtenidos a partir de las correlaciones tanto con el índice de utilidad de carne (Borrero 1990) como de secado (de Nigris y Mengoni-Goñalons 2004) fueron en todos los casos poco significativos, lo que no sugiere una selectividad de partes en función del aporte cárneo o secado. Por su parte, la densidad no habría incidido en la conservación del conjunto, ya que no presenta valores estadísticamente significativos.

A pesar de la presencia de fogones en cubeta, lentes de carbón y ceniza, un porcentaje muy bajo de los restos óseos quedó expuesto a la acción térmica, especialmente en las cuadrículas de los recintos $\mathrm{B}$ y $\mathrm{C}$, donde alcanzan un porcentaje de ca. 9\% (cuantificados en términos de NISP), y algo mayor en el recinto E donde alcanza el 30\% (Calas 2007). En la estructura A se recuperó el contenido de dos fogones dispuestos a nivel del piso original, uno de ellos estructurado (F1) y el otro en cubeta (F2).

Es interesante mencionar que una importante cantidad de restos de roedores fueron identificados al interior de los fogones, lo que reforzaría la hipótesis de una introducción antrópica, especialmente de aquellos pequeños (Phyllotis sp.). Dentro del conjunto de aves se identificó la presencia de Metriopelia sp., ya registrada en el conjunto general (Labarca 2005). De acuerdo con datos etnohistóricos y arqueológicos se reconoce la importancia de roedores (cuy) y camélidos en los diversos ritos andinos, los que eran sacrificados, ofrendados y muchas veces quemados (Eeckhout 2004; Marzal 1983).

Los restos registrados al interior de los recintos que colmataron el templete corresponden al descarte de actividades resultantes en menor medida del consumo de unidades de alto rendimiento que corresponderían a trozamientos independientes como el segmento cervical, lumbar y escápulas junto a otras altamente representadas como la cabeza (cráneo, mandíbula e hiodes), y las extremidades inferiores (metapodios y falanges). Es posible también su relación con la confección de artefactos, ya que se advierte la utilización recurrente de metapodios para la fabricación de artefactos, los que exhiben impactos rebajados por percusión y cuya secuencia de elaboración era iniciada en el exterior del templete (Santander 2009). Al respecto, se han recuperado más de 100 artefactos óseos: propulsores, punzones, espátulas, compresores para talla lítica, cuentas e instrumentos orientados a la textilería, cordelería y procesamiento de pieles e instrumentos para punzar y perforar dedicados al trabajo sobre pieles y cuero (Santander 2009, 2014). De acuerdo con lo anterior, la acumulación de relleno del sitio se produciría en forma intencional derivada tanto de la celebración de comidas ritualizadas y la acción deliberada al introducir restos descartados por procesamiento y producción de artefactos. No obstante, no es posible establecer si todas estas actividades habrían ocurrido al interior o como acciones combinadas con restos de descartes generados in situ y en el exterior, incorporados ritualmente a este espacio como parte de una conducta normada durante los eventos de colmatación del templete. 


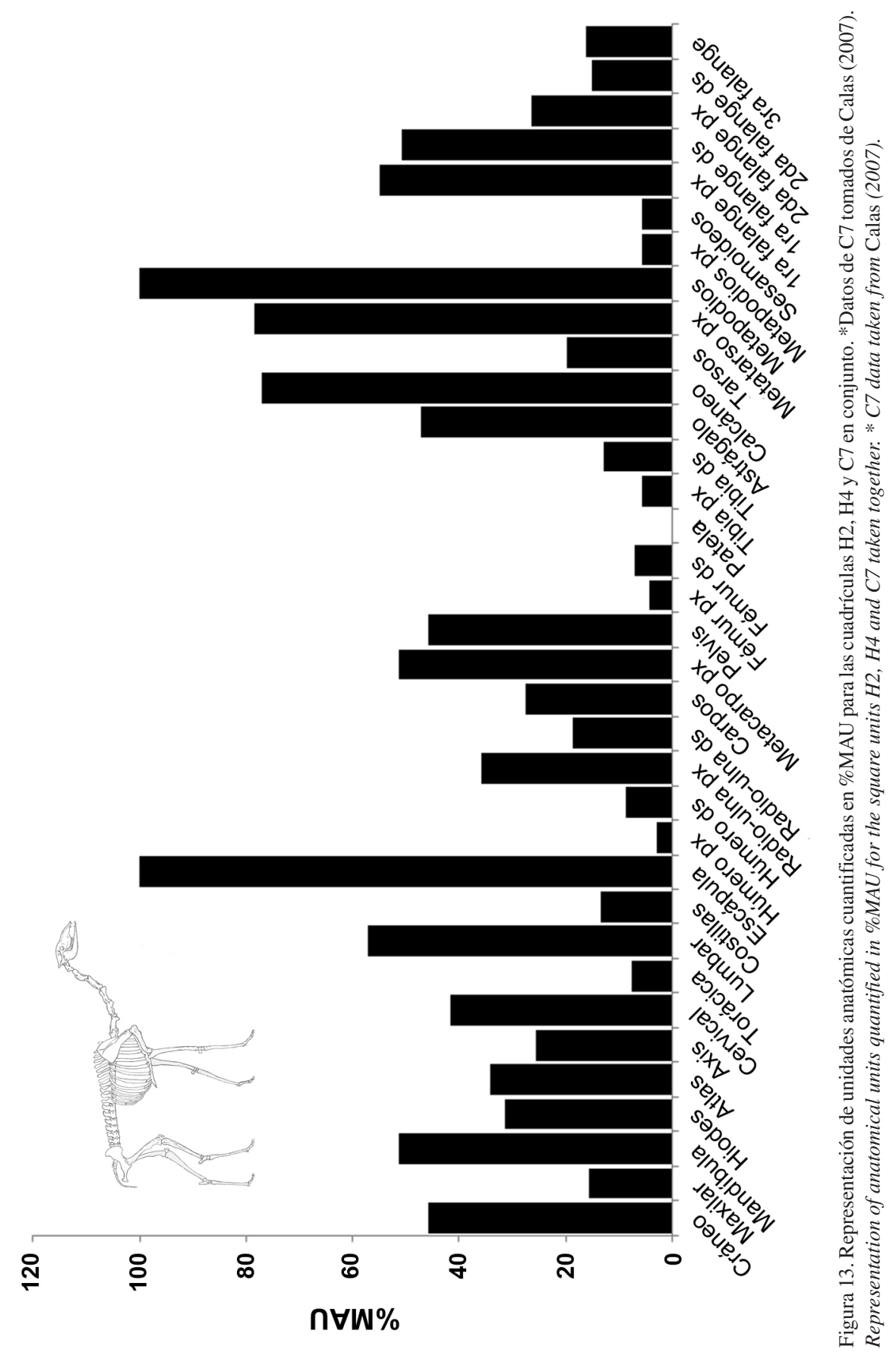




\section{Restos arqueobotánicos}

En general las evidencias recuperadas apuntan a una presencia mayoritaria de vegetales de origen local. Entre los macrorrestos mayormente representados se encuentran Opuntia sp., Scirpus sp., Atriplex sp., brea (Thessaria absinthioides), rica rica (Catholippia riojana), Cortadera atacamensis y en menor medida algunos restos de Prosopis sp. y Geoffroea decorticans y una gramínea (Deyeuxia desertica) útil para la confección de cordelería y cestería verificada en las ofrendas de infantes (McRostie 2014; Núñez, McRostie et al. 2009; Rodríguez 2005). Frutos, semillas, tubérculos y raíces habrían requerido de prácticas de molienda, de modo que la alta frecuencia de manos y metates es coherente con esta alimentación silvestre y subsidiaria. Los frutos de cactáceas verificados en descartes, coprolitos y restos estomacales dan cuenta también de un uso frecuente, al tanto que los tubérculos de Schoenoplectus se utilizaban como alimento, fibra y combustible (Holden 1991).

Los macrorrestos han mostrado cortes bajo y sobre las raíces, reciclándose los residuos en el sitio mismo para combustible y fines artesanales. $\mathrm{Al}$ respecto, un análisis histológico de hojas torcidas de cordelería resultaron ser Poaceae y Juncos sp. (M. F. Rodríguez, comunicación personal 2010). Otros coprolitos y macrorrestos flotados permitieron observar escasas semillas de Sisymbrium sp., de uso seguramente estacional, como un alimento suplementario (Bueno 2004; Holden 1991). Los residuos de Krameria spp., Calandrina sp., raíz de Tessaria absinthioides y Acantholippia riojana, presentan menor valor nutritivo, aunque esta última infusión tiene antecedente etnográfico (McRostie 2014; Núñez, McRostie et al. 2009).

Estos análisis han determinado las escasas prácticas hortícolas de calabaza, quinua y maíz, este último adherido como granos de almidón en instrumentos líticos recuperados en el interior del templete (Babot 2004). Finalmente, se detectaron granos de almidón muy semejante al cebil (cf. Anadenanthera sp.) extraídos de un metate dispuesto como ofrenda en uno de los infantes. Estos antecedentes muestran escasa incidencia de los cultígenos durante la fase Tilocalar, que pudieron usarse en actividades ceremoniales como pudo ocurrir con el maíz, de modo que el rol de la agricultura no fue protagónico (Holden 1991; MacRostie 2014; Núñez, McRostie et al. 2009).

\section{La evidencia mineralógica y lapidaria}

La abundancia local de cobre de color estimuló la confección de cuentas y pendientes vinculadas con las técnicas perforantes, lo que apuntaría a una óptima producción de ornamentos (Figura 14). El proceso extractivo-metalúrgico con variedades de martillos y la presencia de objetos de oro, plomo y cobre, sugieren un particular manejo de técnicas orientadas a producir piezas de alto valor simbólico: láminas de oro ovaladas, rectangulares y cuentas de laminillas. Es común el registro de mineral de cobre triturado aplicado para fundición o esparcidos como challa sobre rasgos rituales intratemplete o en algunos petroglifos contemporáneos ubicados en el transecto Tulán.

La producción excedentaria de estos bienes de prestigio responden a un ambiente rico en minerales orientado al tráfico de interacción de larga distancia, en conformidad con la sobreproducción de cuentas de collares con rocas cupríferas, comunes en el área, incluyendo conchas del Pacífico y del oriente (Carrasco 2002; López Campeny y Escola 2007; Núñez et al. 2007; Rees 1999; Rees y de Souza 2004). Esto explicaría, a su vez, la recepción de otros bienes de estatus desde los valles piemontanos y yungas trasandinas, como caracoles, pipas y cebil para las prácticas psicotrópicas, que posteriormente serán transferidas al uso de tubos y tabletas de inhalación del complejo San Pedro de Atacama (Llagostera 2015; Núñez et al. 2007; Tarragó 1989).

La producción de objetos perforados de lapidaria se registra en gran cantidad y asociación recurrente a microperforadores y desechos de mineral, en áreas aisladas y talleres representando un caso paradigmático. En general, en el sitio Tulán-54 la tipología de cuentas de mineral de cobre en su mayor parte son discoidales de un diámetro promedio ca. 6 mm y de sección rectangular, a lo que se suma una escasa presencia de tubulares (Figura 14).

\section{Los Atributos Rituales}

El diseño arquitectónico del templete albergó actividades ceremoniales recurrentes en sus diferentes recintos. Una rampa angosta desciende hacia el interior del templete, donde los estrechos recintos impiden movimientos más fluidos provocando una circulación restringida. En un comienzo las actividades debieron centrarse en torno a las inhumaciones de infantes, de un modo bastante 


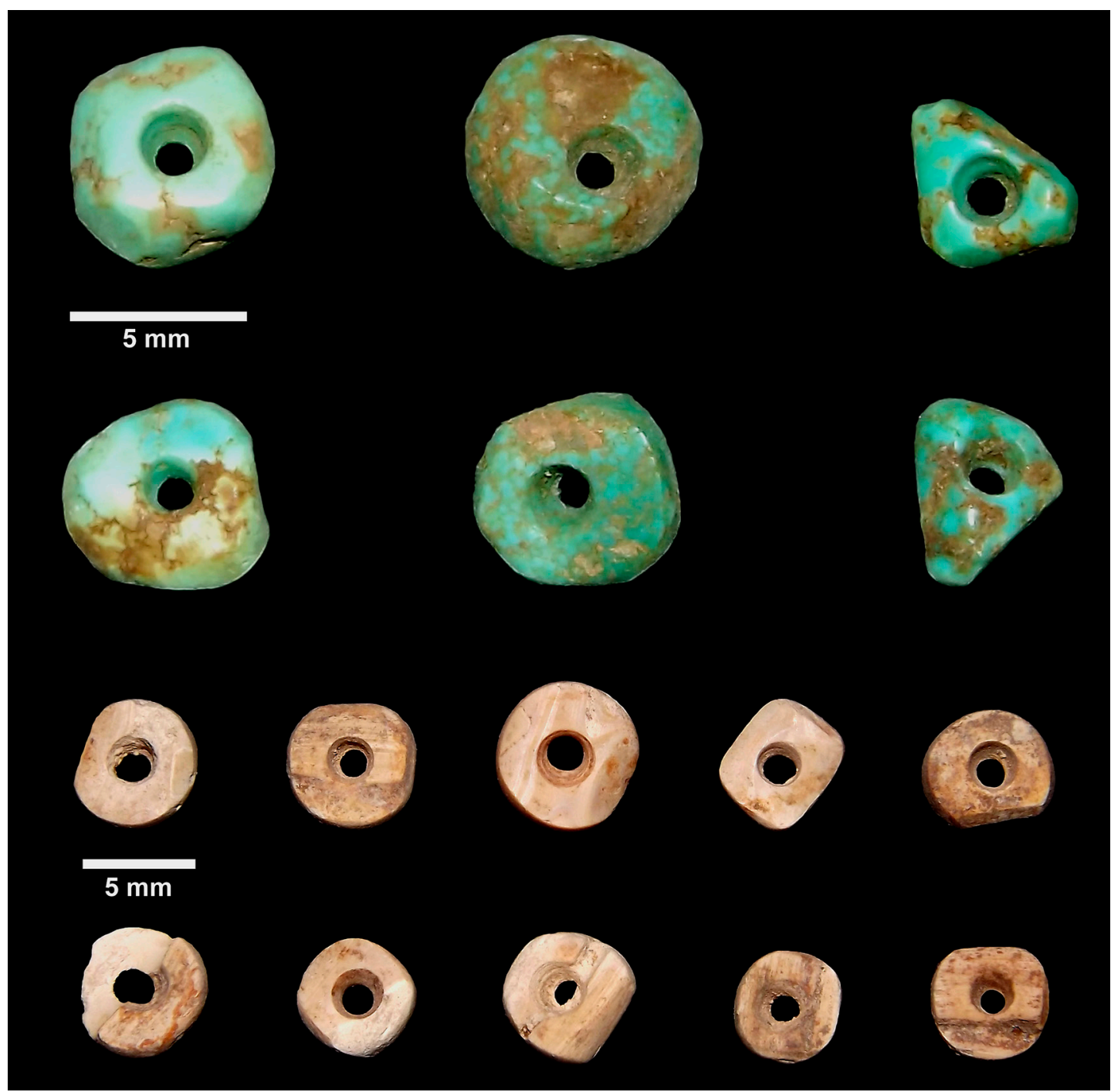

Figura 14. Cuentas de collar recuperadas del sitio Tulán-54.

Bead necklace recovered at the Tulán-54 site.

uniforme en cada uno de los recintos, sumado a actividades de quemas en fogones estructurados junto a grabados y pinturas rupestres, los que se cubrieron gradualmente mediante actividades rituales, comidas y quemas y el descarte continuo de materiales depositados sobre el piso original.

A comienzos de la ocupación, el rito se centró en las inhumaciones de 27 infantes bajo un patrón similar, a pesar de las variaciones etarias y de ofrendas depositadas en fosos socavados en el piso con instrumentos pesados y aguzados con talones reservados (similares a hachas de mano), de acuerdo con las evidencias recuperadas in situ.
Los cuerpos se dispusieron individualmente, salvo un registro doble y otro triple, todos fueron puestos en posición decúbito lateral, semiflectados (Núñez et al. 2006a, 2006b), con ofrendas de collares y objetos preferentemente sobre el cráneo y tórax. Llama la atención en un caso la concentración de carbón bajo el cráneo. Los cestos tipo coiled corresponden a piezas completas en muy mal estado de conservación, bajo o sobre los cuerpos a modo de tapas o contenedores. Una vez terminada la disposición de las ofrendas, solían poner lajas horizontales cubiertas de rellenos procedentes del socavado, hasta nivelarse a la altura del piso. 
La edad de los infantes oscila mayoritariamente entre seis y 12 meses, aunque se encuentra un individuo fetal y dos entre 2 y 4 años (Costa 2005). Los análisis de coprolitos recuperados en el sitio sugieren una población en términos generales sana, donde las patologías infecciosas no habrían tenido efectos fatales y el consumo de alimentos vegetales silvestres complementó el consumo cárneo, sugiriendo que la población no se encontraba sometida a un estrés alimenticio (Holden 1991; Núñez, McRostie et al. 2009). Es por esta razón que, considerando el patrón etario recurrente, se ha postulado la hipótesis de posibles inmolaciones, práctica documentada en el registro etnohistórico (Calancha 1936 [1638]; Arriaga 1968 [1621]).

Las ofrendas corresponden en su mayoría a objetos excepcionales, escasamente representados en los depósitos estratificados del templete, ya sean de origen local o foráneo. A pesar de que la cerámica fue ampliamente utilizada en el sitio, solo en ocho de las inhumaciones se encuentran escasos fragmentos. Las cuentas de caliza, mineral de cobre o conchas del Pacífico y del oriente también se observan ampliamente representadas, tal como ocurre con los caracoles trasandinos (Strophocheilus oblongus) usados como fragmentos perforados; y en un caso, relleno con pigmento rojo en su interior. Otras ofrendas dan cuenta de cubiletes líticos grabados, estólicas de hueso, punzones, láminas de oro repujadas, una placa de plomo, metates y una figurina ornitomorfa (Núñez, Cartajena et al. 2009).

En dos de las inhumaciones se registraron grandes cubiletes cilíndricos grabados. Ambos están "matados", uno perforado y el otro fracturado en cuatro piezas, de igual modo, una lámina de oro con rostros opuestos totalmente enrollada. En el cubilete ofrendado en el centro del templete $(\mathrm{C} 1$, recinto $\mathrm{F})$ se advierte el motivo de un camélido humanizado, mientras que en el otro (C16 y 17, recinto D) se observan dos camélidos erectos también con manos humanizadas, enfrentados hacia un personaje central (Figura 15a). La vestimenta de este personaje central es muy similar a una pequeña figura lítica recuperada en el cementerio de Chorrillos en la cuenca del Loa Medio (Figura 15b).

Asociado al cubilete, junto al muro perimetral, se ubicó en la boca de uno de los infantes, un tapón de madera que representa una cabeza de cóndor cubierta de oro repujado y pigmentado de rojo, con incrustación de cobre de color en la cresta y su cavidad ocular (Figura 16a-e). Este hallazgo es similar a tres tapones de madera registrados en un cementerio Formativo al este de Pisagua (Colección A. Loayza) que representan a cabezas de ave y camélido además de uno sin diseño zoomorfo (Núñez 1964; Figuras 16b, 16c, 16d, 16e).

Por otra parte, se ha reconocido la similitud entre las láminas de oro de cabeza radiante, en forma de colgante, con diseño antropozoomorfo opuesto (C2, recinto F, Figura 17a-b), con aquella proveniente del cementerio Formativo Temprano de Guatacondo (Meighan 1980), correspondiente a una lámina de oro ovalada similar con rostro radiado y representación alada. En otro caso, llama la atención la similitud entre una lámina rectangular de oro con puntos repujados en un extremo dispuesta como
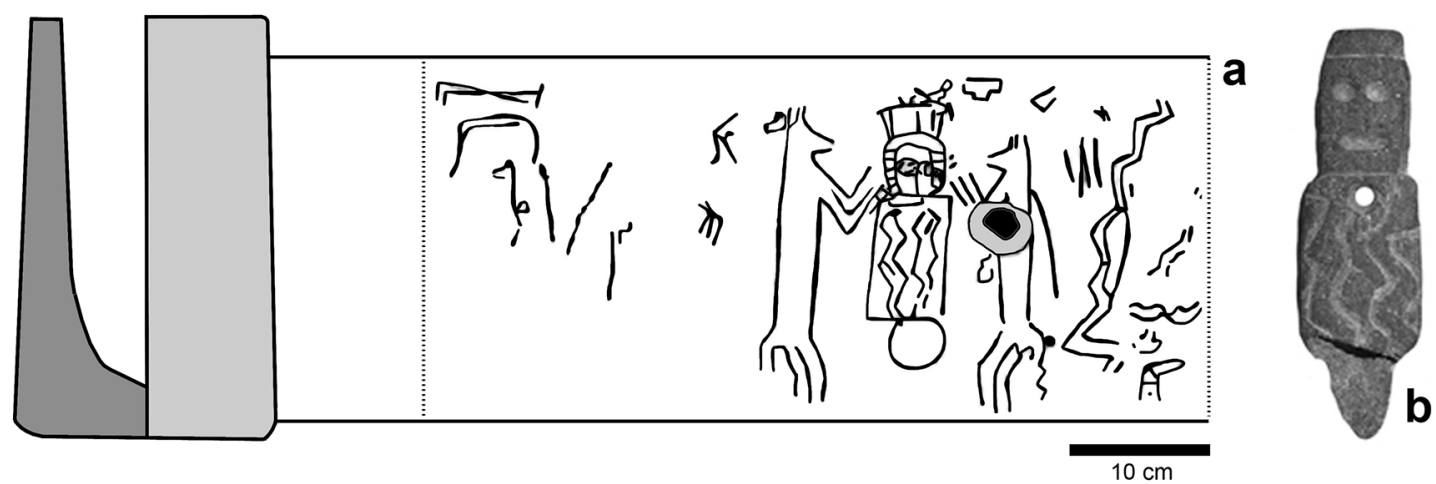

Figura 15. (a) Cubilete lítico grabado registrado como ofrenda en un entierro doble en el recinto D (C16, C17). Se observan dos camélidos erectos humanizados enfrentados hacia un personaje central, (b) Pequeña escultura lítica proveniente del cementerio formativo de Chorrillos (Calama) que presenta un personaje frontal.

(a) Engraved stone vase offering at the double burial in the D unit (C16, C17). Facing a central figure, two humanized camelids stand erect, (b) Small stone sculpture presenting a frontal figure, found at the Formative cemetery of Chorrillos (Calama). 


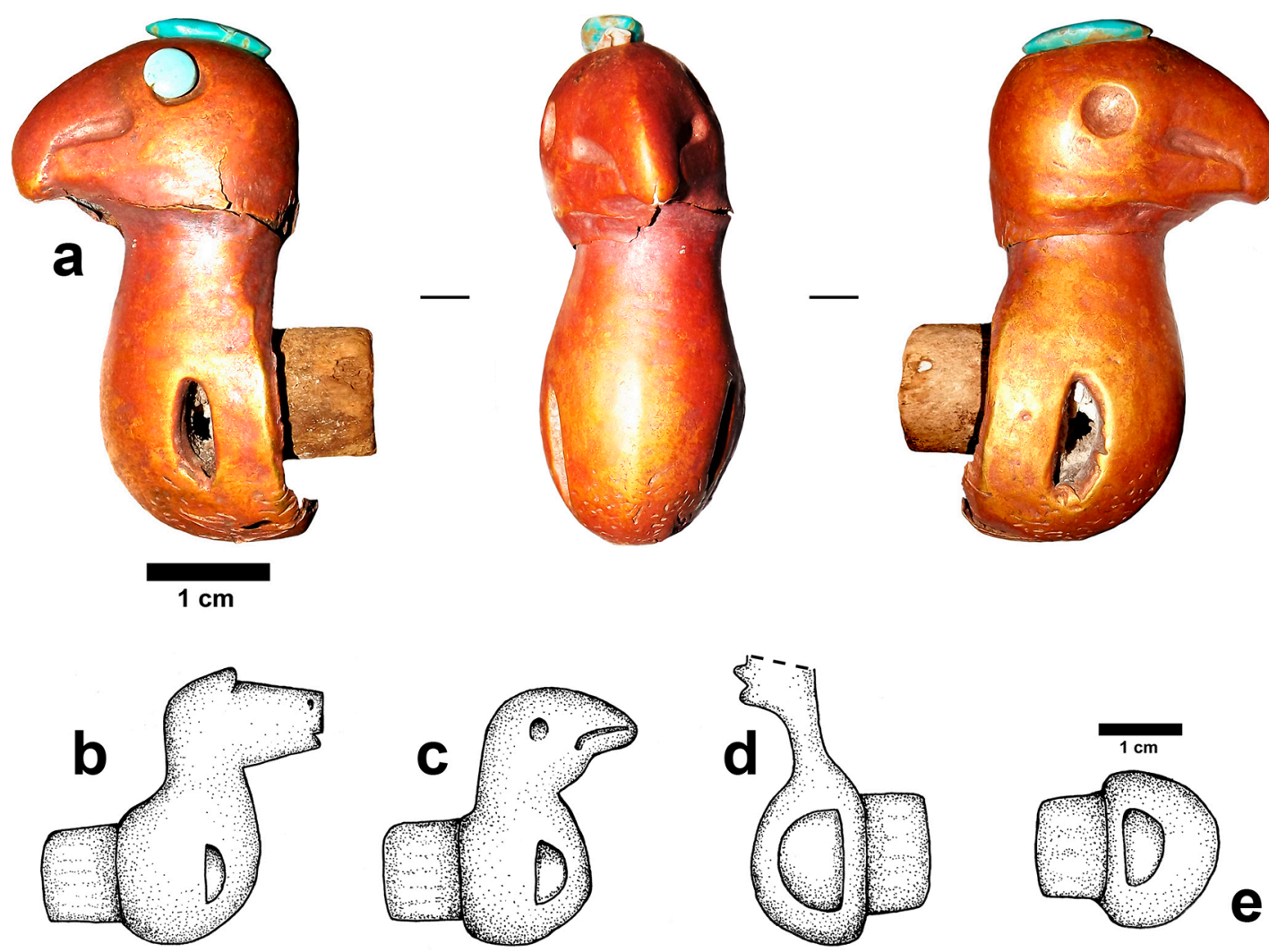

Figura 16. (a) Cabeza de cóndor de oro repujado sobre matriz de madera con incrustación de cobre en la cresta y cavidad ocular izquierda, que fue ofrendada a un neonato al interior del templete Tulán-54. La línea inferior ilustra objetos de madera como tapones hallados en un cementerio Formativo al pie del acantilado de Pisagua por el profesor Alfredo Loayza en 1960 (Colección privada): (b). Cabeza de camélido, (c) Cabeza ornitomorfa con restos de plumillas adheridas, (d) Cabeza de camélido (?) fracturada, (e) Objeto similar sin diseño. Carecen de repujado en oro, pero las formas y tallado ornitomorfo igualan al registro del templete (Núñez 1964). (a) Embossed gold head of condor on a wooden matrix, with copper inlay in the comb and in the left eye cavity. It is an offering to a newborn buried inside the Central Ceremonial Structure of the Tulán-54 site. At the bottom, wooden objects such as caps found in a Formative cemetery in Pisagua by Professor Alfredo Loayza in 1960 (private collection): (b) Camelid head, (c) Ornithomorphic head figure with attached feather remains, (d) Fractured camelid head (?), (e) Similar objects without design. They are not embossed in gold. Both their form and their ornithomorphic carving resemble the ones observed in the Central Ceremonial Structure (Núñez 1964).

ofrenda (C6, recinto C), con aquella proveniente del noroeste argentino, exhibida en el museo de Cachi. También es similar a otras del Formativo Temprano de Arica, una de ellas rectangular con puntos repujados en sus extremos y otra en forma de óvalo con un típico calado rectangular en el centro (Núñez, Cartajena, Carrasco et al. 2011).

Las fechas asociadas a los infantes $\mathrm{C} 4 \mathrm{y}$ C5 (2850 a 2720 cal. a.p.) y C1 (2760 a 2340 cal. a.p.), incluyendo una directa del hueso de una inhumación en C10 (2780 a 2370 cal. a.p.), señalan la redundancia de estas prácticas en un rango temporal acotado, bajo un patrón normado y recurrente. Estas ofrendas denotan la importancia tanto de los objetos de oro como de los cubiletes elaborados en roca volcánica local, que representan elementos iconográficos de escala local y regional. En el primer caso se destaca el camélido con manos humanizadas que se repite a modo de un felino con similares atributos identificado en un petroglifo mueble asociado a una estructura extratemplete. En el segundo caso se trata del personaje frontal esta vez replicado en un pequeño lito grabado en el Loa Medio, entre los materiales rescatados del cementerio formativo de Chorrillos.

La ritualidad en los fogones estratificados sobre el templete se expresa en desechos de contenedores, consumo, implementos de molienda e incluso 

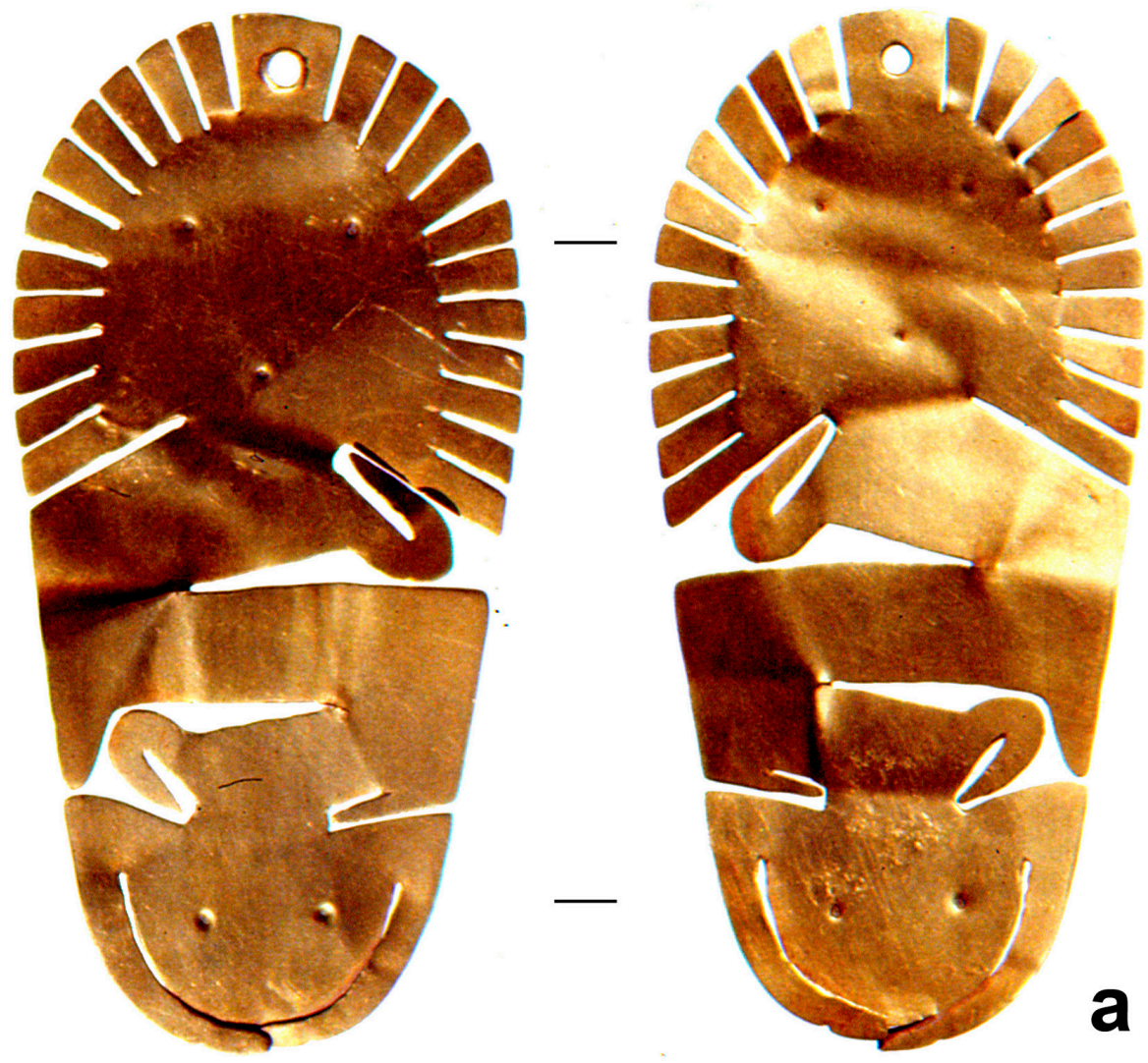

$1 \mathrm{~cm}$

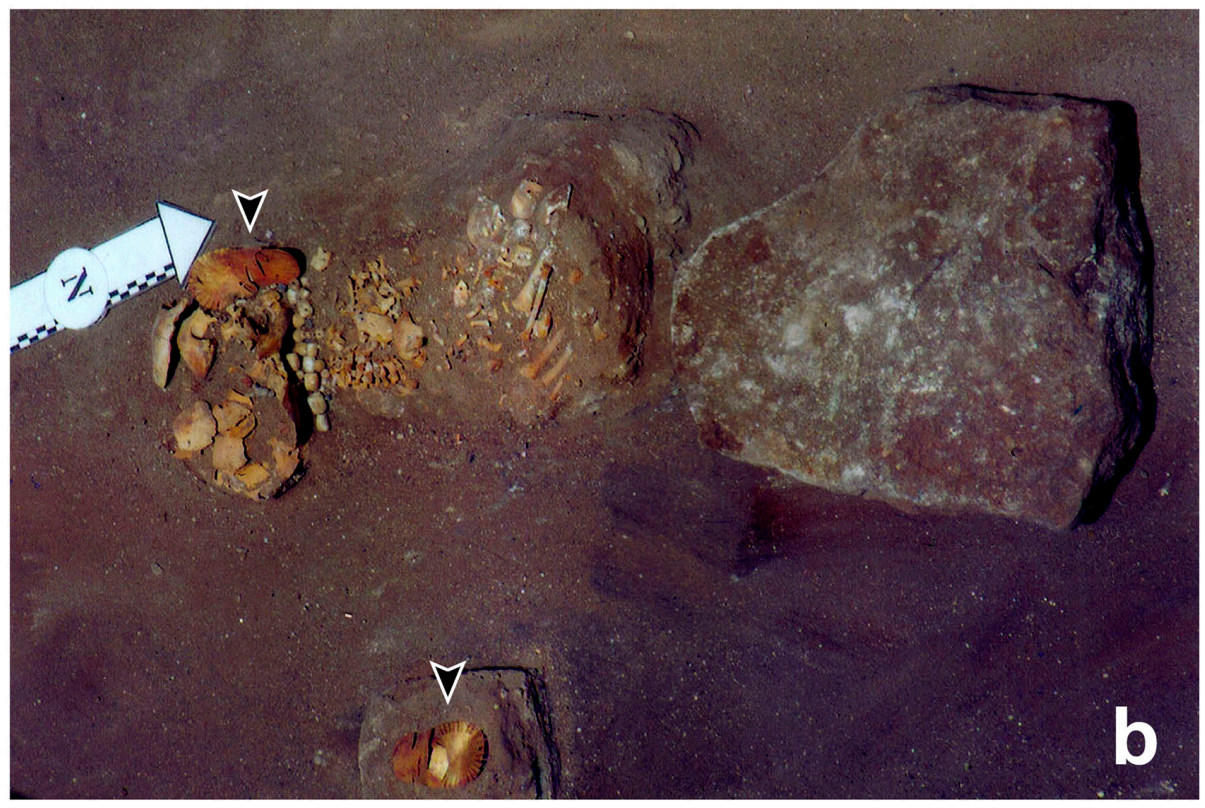

Figura 17. (a) Láminas de oro con perforación (colgante) y repujado de dos cabezas opuestas dispuesta como ofrenda en el entierro C13 (recinto D), (b) Láminas y el cuerpo in situ, junto a la laja que lo cubría. (a) Perforated laminated gold sheets (pendant) with two facing embossed heads, deposited as an offering at the C13 burial (D unit), (b) The two gold sheets and the human remains in situ, next to the slab that covered them. 
fecas de la evisceración derivada de los descartes de restos de camélidos. En los fogones del piso del templete, dispuestos junto a los fosos de las inhumaciones, se recuperaron restos mínimos de camélidos, aves y roedores y partículas de mineral de cobre, asociadas a cuentas de crisocola y microperforadores. Se admite que estas "quemas" servirían como las "mesas" e incensarios, tal como ocurre con el ceremonial etnográfico local y en el altiplano donde el "hacer pasar" la ofrenda a las brasas, incluye a fetos de llamas, incineración de plantas aromáticas y resinosas: coca, coa y copal (Rösing 1994:115).

El aparato ritual se centralizó en actos e imágenes redundantes donde el arte rupestre representa hasta ahora la única evidencia de la Circumpuna al interior de una estructura ceremonial, con petroglifos representando diferentes escenas y diseños (Figura 18a-b). Estos, replican estilos que a nivel regional han sido denominados Taira-Tulán, caracterizados por grandes grabados y pictograbados de camélidos naturalistas; y Confluencia correspondiente a pictografías pequeñas con figuras humanas asociadas a propulsores, faldellines y escenas de caza de camélidos (Berenguer 1999; Gallardo et al. 1999; Núñez, Cartajena, Carrasco y de Souza 2006; Núñez, Cartajena, Carrasco et al. 2011). El primero se localiza en sitios abiertos, relacionado a grandes bloques y acantilados en quebradas ubicadas desde la cuenca del Loa hasta el sur del salar de Atacama, asociado a ritos vinculados con camélidos domésticos (Berenguer 1999). En el caso del estilo Confluencia las pinturas se encuentran en el río Salado, especialmente al interior de abrigos y representarían animales silvestres asociados a escenas de cacerías (Gallardo y Yacobaccio 2005). Precisamente, bajo el bloque con pinturas del estilo Confluencia se ubicó en el templete la inhumación de un infante con dos propulsores de hueso, similares a los ofrendados en el abrigo Tulán-109, en la banda opuesta de la quebrada, con grabados de camélidos TairaTulán, similares a los registrados en el Loa medio (Pollard 1970).

A pesar de que ambos estilos pertenecerían a un período caracterizado por economías mixtas, cada uno apuntaría a diferentes orientaciones económicas e ideológicas esta vez en un contexto sincrónico. En efecto, la evidencia osteológica de la fase Tilocalar señala que la caza de camélidos era tan frecuente como la crianza y que el arco coexistía con propulsores en cuanto las prácticas de caza y pastoralismo eran simultáneas. La caza, si bien formó parte del sistema económico, también debió actuar como un catalizador ante las tensiones producidas por la crianza de animales domésticos. Sin embargo, ambas modalidades reflejarían conductas iconográficas diferentes pero derivadas de modos contemporáneos de vida y subsistencia (Aschero 2006). En cuanto los ritos rupestres intratemplete, ocurrieron en bloques apoyados en el piso fundacional, se supone que estos sucedieran al mismo tiempo en que se socavaba el piso para depositar a los infantes, entre $3050-2770$ y 2870 2740 años cal a.p.

En general, los ritos intratemplete sugieren la integración a un discurso macrorregional sustentado por el surgimiento de liderazgo y la circulación de objetos de estatus e iconos promovidos a través del tráfico de interacción de amplia escala entre comunidades dispuestas entre la costa/valles bajos, hasta la vertiente trasandina, incluyendo las altiplanicies, los valles altos y las tierras bajas agrícolas del Amazonas. La presencia en contextos formativos tempranos de objetos exóticos y prestigiosos extralocales dan cuenta de los contactos de larga distancia reflejados en el templete: implementos fumatorios, cebil, cerámica unguiculada e imbricada, caracoles orientales, adornos óseos para turbantes, maíz, semillas, conchas del Pacífico, obsidiana, cuentas de conchas foráneas, plumas, maderas intrusivas y objetos metálicos, entre otros, asociados a ofrendas, escondrijos e inhumaciones (Escola et al. 2005; Gallardo y Cabello 2015; Núñez y Santoro 2011). Efectivamente, se ha detectado durante tiempos formativos tempranos un incremento de las redes de interacción regional con intercambios de larga distancia entre la costa del Pacífico, las altiplanicies y la vertiente trasandina, a través de la circulación de bienes de prestigio que sugieren interconexiones multidireccionales (Browman 1991; Núñez et al. 2007).

\section{Reflexiones Finales}

Una de las claves en las tierras altas del sur para comprender la emergencia de complejidad ritual radica en identificar la transferencia de los logros arcaicos tardíos a los asentamientos formativos y la posibilidad cierta que en ese espacio surgiera un modo de vida eficiente que combinara caza y pastoralismo (Núñez 2006; Núñez et al. 1999). 


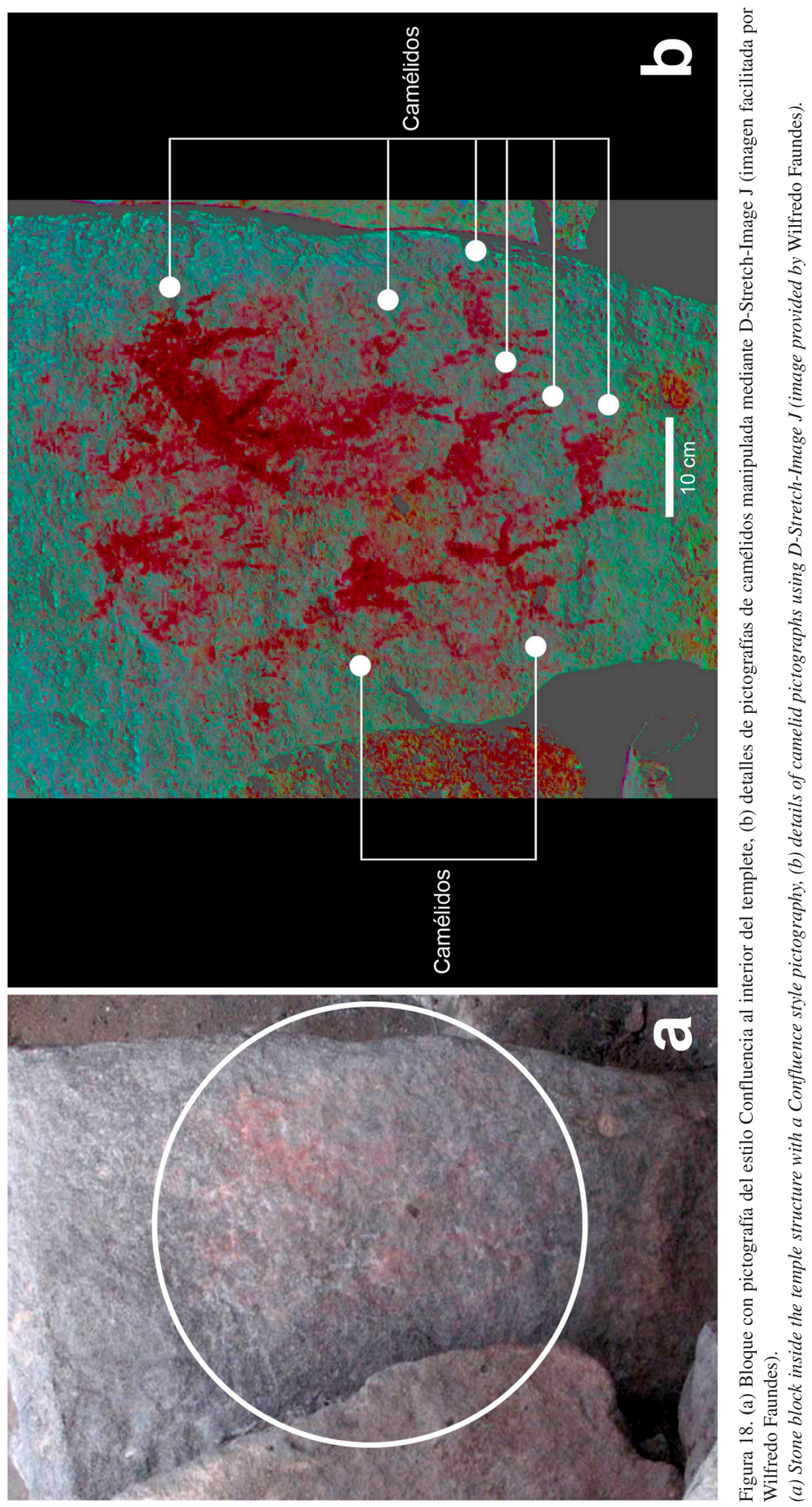


Sin embargo, no son comunes estos sitios en el sur andino como para establecer comparaciones adecuadas. A pesar de los múltiples estudios en las tierras altas, es poco conocida la funcionalidad de los sitios ceremoniales formativos (Roddick $2002,2008)$. Se ha propuesto que la arquitectura monumental, montículos y plataformas, pudieron congregar actividades rituales cíclicas ligadas a festines, que darán lugar a una política de comensalismo y encuentros festivos competitivos en el marco de mano de obra conducida por un liderazgo emergente (Dietler y Hayden 2001; Dillehay 2005; Hastorf 2008a, 2008b; Ikehara y Shibata 2005; Stanish 2003; Steadman 2002). Sin embargo, en el caso del centro ceremonial de Tulán se estaría en presencia de un patrón circumpuneño distinto a las grandes congregaciones y festines competitivos propuestos para el altiplano central. Al considerar los indicadores comúnmente utilizados, especialmente la parafernalia asociada al servicio de comidas y bebidas; en el templete se observa el predominio de formas restringidas relacionadas con el despliegue y servicio de alimentos y líquidos, también se registra un número de vasijas grandes (Kalazich 2006). Lo anterior es consistente con las observaciones que indican que no solo un alto número de vasijas para servir, sino también la presencia de grandes vasijas para cocinar y almacenar, serían indicadores de actividades festivas (Roddick 2002).

Pese a lo anterior, en el templete de Tulán los residuos de la estratificación monticular son más compatibles con las "mesas" y comidas etnográficas andinas que permiten por reciprocidad satisfacer el apetito de los seres tutelares, como achachila, quien es el dueño y antepasado de la comunidad y también propietario del ganado silvestre y doméstico, incluyendo la lluvia (Fernández 1994). Se cumplen por la deuda de ofrenda, recibiendo alimentos, sacrificios y rogativas, porque controlan las fuerzas de la naturaleza. Viven en cerros, vertientes, lagunas y otros lugares sagrados y desde allí son invocados a un espacio de interlocución en las "mesas" y "nidos de ofrenda" (BouysseCassagne y Harris 1987; Rösing 1994:201-210). Se mantiene el carácter hereditario de la deuda de ofrenda, esto es, la reiteración generacional de los ritos, en tanto hoy, como posiblemente en el Formativo Temprano, las deidades son atendidas y reverenciadas con comidas y bebidas cíclicas (Dillehay 2005; Rösing 1994).
Los linajes familiares y fundacionales asumirían liderazgos religiosos en la medida que atenuaron conflictos derivados del acceso desigual al ganado y bienes de prestigio. Es posible que las cuotas del trabajo comunitario en eventos temporales se hayan realizado bajo un régimen de desigualdad aún incipiente. Ciertamente, gran parte de los objetos que componen el relleno del templete son abundantes y se encuentran presentes también en los contextos domésticos de otros sitios de la región. No se observa un acceso restringido a los recursos, por el contrario, se sugiere una participación inclusiva estimulada por el acceso reiterado al centro ceremonial. El uso de pipas y consumo de psicotrópicos intratemplete podrían vincularse con prácticas chamanísticas y se podría especular que más de algún rito reflejado en las evidencias registradas tenga relación con el efecto alucinante.

Se habrían formalizado ceremonias propias como la incorporación de los ritos rupestres regionales y el énfasis en el rol de los infantes en una liturgia local, conformando un axis mundi circumpuneño, acentuándose el rol de los infantes percibidos como seres inmaculados, al margen de la socialización, al servicio de rogativas trascendentes. Las inmolaciones en el templete serían actos fundacionales vinculados con el acceso a los númenes y poderes ancestrales, considerando a los infantes como intermediarios ante el panteón andino. El espíritu fuera de los cuerpos pudo captarse como un umbilicus con los poderes requeridos por la comunidad durante sus actos públicos. En cuanto el espíritu de los antepasados (achachila) posee los lugares benignos y malignos: montañas, animales, lluvias, sequías, vientos, muertes y vertientes, es a ellos donde se deben conectar las ofrendas, quemas, festines y rogativas (Arriaga 1968 [1621]; Bouysse-Casagne y Harris 1987; Calancha 1936 [1638]).

Las comidas ritualizadas que cubrieron el templete más bien se acercan a las ceremonias homólogas actuales que: "penetran profundamente en la vida cotidiana y la vida cotidiana se inserta profundamente en el ritual” (Rösing 1994:197), sustentadas en "maestros" que convocan a los "convites" (Fernández 1994). Ciertamente, la impresión de los últimos pastores de Peine-Tulán acerca de los abundantes restos óseos superficiales de estos sitios es que aquí los antepasados celebraban sus "festejos" (Estanislao Ramos, comunicación personal, 2010). La comida abundante, remarcada por la abundancia de desechos, las valoran en lugares 
de "encuentros". Es más, aun estas ofrendas se entierran, tal como sucede con el espacio del rito "cabildo" del altiplano (Rösing 1994). Parece cierto que las acciones numinosas involucraron comidas y pasajes rituales integrando valores profanos y ceremoniales (Burger y Burger-Salazar 1985; Eliade 1959), compatibles con el ceremonialismo formativo donde: "lo ritual y lo doméstico no son necesariamente mutuamente opuestos" (Hastorf et al. 2001:36).

Por otra parte, el registro de ofrendas ("pagos") en los fosos del templete reitera también actos panandinos, tal como ha ocurrido en los pisos de aquellos templos arcaicos-formativos de la costa de los Andes centrales (Makowski 2005). Se trataría de un indicador arqueológico y etnográfico persistente en el Centro Sur andino (p.ej. "nido de ofrendas", "covero"), relacionados con protección en rutas, requerimiento de agua, multiplico de ganado y otras demandas que implican gratitud (Rösing 1994). Se depositan al interior de la tierra hacia los alcances de Pachamama, asociados a las "quemas" de inciensos, libaciones, festines y el esparcido votivo de challa (Fernández 1994). Por su parte, en la etnografía local se observa también una estrecha relación entre la colocación simultánea de ofrendas en fosos tapados con lajas planas junto a la fogata donde queman coca y coa, durante el "convido" y la "limpia de canales" en el ceremonial de los “cantales" de Peine/Tulán (Núñez 2011).

El centro ceremonial, al articular el hábitat de Tulán, estimuló el surgimiento de una tradición religiosa compartida en un marco de hábitos cinegéticos y pastoralistas con independencia política e ideológica, en un escenario de amplias redes de intercambio y contactos macrorregionales aún poco conocidos.

Se propone que existieron linajes fundacionales asociados a la conducción de los rituales al interior del templete con acceso a bienes de prestigio. Por un lado, estos provenían de la productividad local observada en los objetos de culto, dispuestos en la funebria intratemplete; $y$, por otro, los recepcionados por el tráfico regional. Ambos constituyen en el templete bienes de uso selectivo y de baja frecuencia.

Recién se conocen las rutas contemporáneas entre el Loa y el litoral, mientras que en el curso medio se han observado densas áreas de inhumaciones con contextos estrechamente vinculados, esta vez con una base hortícola (quinua) y pastoralista, adaptada a tierras más bajas (González y Westfall 2010). Al respecto, se intensificaron las conexiones durante la fase Tilocalar con el litoral y el Loa, expresadas con la presencia de turbantes, productos alimenticios del mar, cerámica Los Morros, conchas del Pacífico y del oriente (p.ej. Strophocheilus), laminillas de oro, pipas y objetos de cobre. Precisamente, las dataciones y contextos de estas evidencias establecen una plena sincronía con los cementerios de Topater (700 a.C.), Chiuchiu-200 (900 a.C.), y las nueve fechas de Chorrillos de las cuales seis se ubican entre los 700-800 a.C. (Benavente 1982; González y Westfall 2010; Thomas et al. 1995).

Las diferencias observadas respecto del altiplano central son sustanciales en relación con el manejo de recursos, escalas espaciales, estabilidad y complejidad, en tanto que la combinación agricultura y pastoralismo generó allí formaciones aldeanas densas y sedentarias. En el caso más meridional de Chiripa, al sur del lago Titicaca, se ha indicado un crecimiento aldeano continuo, donde la actividad ritual y pública habría permitido reducir, resolver o redireccionar los conflictos al interior de los asentamientos fijos, por lo que ha sido considerada como una tecnología social que posibilitó el establecimiento de un sistema aldeano durante el Formativo Medio (Bandy 2001). Precisamente, estas transformaciones ocurrieron en general en aldeas formativas estables apoyadas en horticultura/agricultura, pastoreo de llamas y recolecta de recursos silvestres en un contexto de circunscripción social (Bandy 2001). Más al sur, el complejo cultural Wankarani se había caracterizado por sus asentamientos monticulados conformados por ocupaciones superpuestas de carácter doméstico y ceremonial al integrar inhumaciones, incluyendo un neonato sacrificado, afianzados con una base agrario-pastoralista aldeana y sedentaria (Bermann y Estévez 1995; Estévez 1999; Fox 2010; McAndrews 2005; Ponce 1970; Rose 2001; Walter 1966).

Sin embargo, recientemente se ha propuesto en Wankarani una orientación exclusiva pastoralista temprana, constituida por comunidades móviles a base de múltiples asentamientos dispersos conectados a estructuras residenciales (Capriles 2014, 2016; Capriles et al. 2011). A diferencia de los asentamientos Chiripa de más al norte, estas comunidades no se caracterizarían por grandes aldeas sedentarias asociadas a arquitectura pública monumental. Lo anterior pone de manifiesto un modelo de pastoreo andino con un grado mucho mayor de movilidad, por el uso recurrente de 
espacios habitacionales, asociados a áreas de pastoreo estacionales, como también a algunos sitios de agregación que posiblemente tuvieron un carácter ceremonial como Machacamarca y Pukara de Belén. Estos últimos estarían representados por una alta profusión de esculturas líticas de cabezas de camélidos, atributos especiales que sugieren una expresión ideológica pastoralista que recuerda al grabado en el templete de Tulán (Capriles 2016; Capriles et al. 2011; McAndrews 2005).

En este escenario, sería importante definir un modelo comparativo entre la naturaleza de las ocupaciones formativas tempranas de las subáreas Altiplano Meridional y Circumpuna desde la perspectiva del tránsito Arcaico-Formativo y la emergencia de complejidad sustentada en modos de vida dinámicos de caza y pastoralismo, con asentamientos complementarios entre sí, integrados en un locus sanctus común, localizado en uno o más centros prestigiosos de convergencia cíclica o estacional (Núñez et al. 2006a, 2006b). Por lo anterior, es probable que gran parte de los rituales pudieron vincularse con la construcción de un liderazgo local basado en la integración y cohesión con comunidades pastoralistas emergentes, sujetos a una dependencia política segmentada, fundada quizás en el parentesco, como una forma de asegurar los derechos comunales, familiares o individuales (Capriles 2016).

A través de la fase Tilocalar se explicaría la ubicación de un conjunto de asentamientos densos y diferenciados, localizados en el transecto Tulán, conformando un hábitat integrado con relaciones mutualistas articulado en el intermedio por un centro ceremonial. Estos sitios se diferencian de las aldeas agrícolas formativas sedentarias al basarse en un equilibrio entre movilidad y estabilidad, en un marco de hábitos cinegéticos y pastoralistas, aglutinados en una esfera cosmológica y ritual consolidada en la quebrada Tulán. Habrían aceptado un panteón protector que regula los sucesos terrenales durante el Formativo Temprano, cuando se inicia el desvanecimiento del universo arcaico, mientras que desde el ideario pastoralista creciente se enfrentaba a trasformaciones formativas desconocidas. Ni antes o después fue tan necesario el soporte religioso para superar los riesgos implicados en la emergencia de nuevos modos de vida. A diferencia de otros procesos andinos donde la forma construida se preserva como un testimonio visual, después de tanta energía invertida, el templete de Tulán quedó gradualmente oculto bajo el montículo sagrado: habían preferido el mito por sobre el testimonio visible.

Agradecimientos: Los autores agradecen a la comunidad atacameña de Peine por su apoyo y colaboración permanente al proyecto. Esta investigación es resultado del actual proyecto FONDECYT 1130917, que nos ha permitido continuar con la problemática del sitio Tulán-54, sumado al anterior proyecto FONDECYT 1070040. Las excavaciones contaron con la autorización del CMN No de oficio 4419/13. Por otra parte, ha sido muy importante la incorporación de todas(os) las(os) colegas que han participado en los múltiples trabajos de campo y análisis, en los distintos proyectos realizados en quebrada Tulán. Se suman las(os) alumnas(os) practicantes y tesistas cuyas contribuciones han sido esenciales. Finalmente se agradece a los evaluadores anónimos de Chungara Revista de Antropología Chilena, que contribuyeron sustancialmente a mejorar el manuscrito.

\section{Referencias Citadas}

Arriaga, P.J. 1968 [1621]. La extirpación de la idolatría en el Perú. Biblioteca de Autores Españoles 209:191-277.

Aschero, C. 2006. De cazadores y pastores. El arte rupestre de la modalidad río Punilla en Antofagasta de la Sierra y la cuestión de la complejidad en la puna meridional. En Trama en la Piedra. Producción y Usos del Arte Rupestre, editado por D. Fiore y M. Podestá, pp. 103-140. Sociedad Argentina de Antropología, Asociación de Amigos del Instituto de Antropología y World Archaeological Congress, Buenos Aires.

Ayala, P. y M. Uribe 2003. La cerámica Wankarani y una primera aproximación a su relación con el período Formativo del Norte Grande de Chile. Textos Antropológicos 14:7-30.
Babot, M.P. 2004. Tecnología y Utilización de Artefactos de Molienda en el Noroeste Prehispánico. Tesis doctoral, Facultad de Ciencias Naturales e IML, Universidad Nacional de Tucumán, San Miguel de Tucumán.

Bandy, M.S. 2001. Population and History in the Ancient Titicaca Basin. Tesis Doctoral, Universidad de California, Berkeley.

Benavente, A. 1982. Chiu Chiu 200: Una comunidad pastora temprana en la Provincia del Loa (II Región). Actas del IX Congreso Nacional de Arqueología Chilena, editado por la Sociedad Chilena de Arqueología, pp. 75-94, La Serena.

Berenguer, J. 1999. El evanescente lenguaje del arte rupestre en los Andes atacameños. En Arte Rupestre en los Andes de 
Capricornio, editado por J. Berenguer y F. Gallardo, pp. 21-30), Museo Chileno de Arte Precolombino, Santiago.

Bermann, M. y J.C. Estévez 1995. Domestic artifact assemblages and ritual activities in the Bolivian Formative. Journal of Field Archaeology 22:389-398.

Borrero, L.A. 1990. Fuego-patagonian bone assemblages and the problem of cormunal guanaco hunting. En Hunters of the Recent Past, editado por L.B. Davis y B.O.K. Reeves, pp. 37399. Unwin Hyman, Londres.

Bouysse-Casagne, T. y O. Harris 1987. Pacha: Entorno al pensamiento aymara. En Tres Reflexiones sobre el Pensamiento Andino, editado por T, Bouysse-Casagne, pp. 11-59, Hisbol, Biblioteca Andina 1, La Paz.

Browman, D. 1991. The dynamics of the Chiripa polity. Ponencia presentada al $47^{\text {th }}$ International Congress of Americanists, July 7-11, Tulane University, New Orleans.

Bueno, L. 2004. Flotación en Tulán-85. Informe de Práctica Profesional, Departamento de Antropología, Facultad de Ciencias Sociales, Universidad de Chile, Santiago. Manuscrito en poder de la autora.

Burger, R.L. y L. Burger-Salazar 1985. The early ceremonial center of Huaricoto. En Early Ceremonial Architecture in the Andes, editado por C.B. Donnan, pp. 111-138. Dumbarton Oaks Research Library and Collection, Washington D.C.

Calancha, Fray A. de la 1936 [1638]. Crónica Moralizadora del Orden de San Agustín en el Perú. Con Sucesos Ejemplares Vistos en esta Monarquía. Pedro Lacavallería Impresores, Barcelona.

Calas, E. 2007. Análisis de un conjunto arqueofaunístico formativo temprano: Templete Tulán-54, estructura E. Informe Práctica Profesional, Departamento de Antropología, Universidad de Chile, Santiago. Manuscrito en poder de la autora.

Capriles, J. 2014. Mobile communities and pastoralist landscapes during the Formative Period in the central altiplano of Bolivia. Latin American Antiquity 25:3-26.

Capriles, J. 2016. Arqueología del pastoralismo temprano de camélidos en el altiplano central de Bolivia. Institut Français d'Études Andines. En Prensa.

Capriles, J., S. Calla y J. Albarracín-Jordán 2011. Tecnología lítica y estrategias de subsistencia entre los períodos arcaico y formativo en el altiplano central. Chungara Revista de Antropología Chilena 43:455-468.

Carrasco, C. 2002. Las industrias líticas de Quillagua. Estudios Atacameños 22:33-58.

Carrasco, C. y P. De Souza 2009. Informe de análisis de material lítico sitio Tu-85. Informe de avance de proyecto FONDECYT 1070040. Manuscrito en poder de los autores.

Cartajena, I. 2003. Análisis de las colecciones arqueofaunísticas de los sitios Tulán 52 (TU-52), 54 (TU-54), 55(TU-55), 57 (TU57), 67 (TU-67) y 85 (TU-85). Informe de Avance Proyecto FONDECYT 1020316. Manuscrito en poder de la autora.

Cartajena, I. 2009. Explorando la variabilidad morfométrica del conjunto de camélidos pequeños durante el Arcaico Tardío y el Formativo Temprano en quebrada Tulán, norte de Chile. Revista del Museo de Antropología 2:199-212.
Cartajena, I., L. Núñez y M. Grosjean 2007. Camelid domestication in the western slope of the Puna de Atacama, Northern Chile. Anthropozoologica 42:155-173.

Costa, M.A. 2005. Informe de determinación de edad de individuos infantiles del sitio Tulán-54. Informe 1 y 2 de avance, Proyecto Fondecyt 1020316. Manuscrito en poder de la autora.

De Nigris, M. y G.L. Mengoni Goñalons 2004. El guanaco como fuente de carne y grasas en Patagonia. En Contra Viento y Marea. Arqueología de Patagonia, editado por M.T. Civalero, P.M. Fernández y A.G. Guráieb, pp. 469-476. Sociedad Argentina de Antropología e Instituto Nacional de Antropología y Pensamiento Latinoamericano, Buenos Aires.

Dietler, M. y B. Hayden 2001. Feasts: Archaeological and Etnographic Perspectives on Food, Politics, and Power. Smithsonian Institution Press, Washington, D.C. y Londres.

Dillehay, T. 2005. Introducción. Boletín de Arqueología PUCP 9:19-24.

Driesch, A. Von den 1999. A Guide to Measurement of Animal Bones from Archaeological sites. Peabody Museum Bulletins 1. Harvard University, Cambridge.

Eeckhout, P. 2004. Relatos míticos y prácticas rituales en Pachacamac. Boletín de Instituto Francés de Estudios Andinos IFEA 33:1-54.

Eliade, M. 1959. The Sacred and the Profano. Traducido por W.R. Trask. Harcourt Brace y World Inc., Nueva York.

Escola, P., L. Núñez y S. Hocsman 2005. Distribution and circulation of obsidian in Puna de Atacama (ca. 4500-3000 AP). Manuscrito en poder de los autores.

Estévez, J.C. 1999. San Andrés: Un montículo ceremonial de la cultura Wankarani. Informe preliminar, La Paz. Manuscrito en poder del autor.

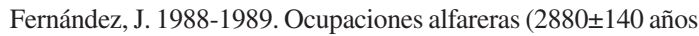
A.P.) en la cueva de San Cristóbal (Puna de Jujuy, Argentina). Relaciones de la Sociedad Argentina de Antropología 17:139-172.

Fernández, G. 1994. El banquete aymara: aspectos simbólicos de las mesas rituales aymaras. Revista Andina 12:155-190.

Fox, J. 2010. A persistent early village settlement system on the Bolivian southern altiplano. En Becoming Villagers: Comparing Early Village Societies, editado por M.S. Bandy y J.R. Fox, pp. 184-204. Amerind Studies in Archaeology, University of Arizona Press, Tucson.

Gallardo, F., C. Sinclaire y C. Silva 1999. Arte rupestre, emplazamiento y paisaje en la cordillera del desierto de Atacama. En Arte Rupestre en los Andes de Capricornio, editado por J. Berenguer y F. Gallardo, pp. 57-96, Museo Chileno de Arte Precolombino, Santiago.

Gallardo, F. y H.D. Yacobaccio 2005. Wild or domesticated? Camelids in Early Formative rock art of the Atacama Desert (Northern Chile). Latin American Antiquity 16:115-130.

Gallardo, F. y G. Cabello 2015. Emblems, Leadership, Social Interaction and Early Social Complexity: The Ancient Formative Period (1500 BC-AD 100) in the Desert of Northern Chile. Cambridge Archaeological Journal doi: 10.1017/ S0959774315000013 
García, L. 1998. Arqueología de Asentamientos Formativos en la Puna Oriental y su Borde, Provincia de Jujuy. El Cambio hacia una Vida Crecientemente Sedentaria y Productiva en Azul Pampa, Departamento de Humahuaca. Tesis para optar al grado de Doctor en Filosofía y Letras, Facultad de Filosofía y Letras, Universidad de Buenos Aires, Buenos Aires.

González, C. y C. Westfall 2010. Cementerio Regimiento Chorrillos de Calama: testimonios funerarios formativos en el Loa medio, región de Antofagasta. Actas del XVII Congreso Nacional de Arqueología Chilena Tomo 1, editado por la Sociedad Chilena de Arqueología, pp. 95-105, Universidad Austral de Valdivia, Valdivia.

Grosjean, M. y L. Núñez 1994. Late glacial, early and middle Holocene environments, human occupation, and resource use in the Atacama (Northern Chile). Geoarchaeology: An International Journal 9:271-286.

Hastorf, C.A. 2008a. Construyendo comunidad, ceremonialismo y memoria social durante el formativo medio en Chiripa, Bolivia. En Arqueología de las Tierras Altas, Valles Interandinos y Tierras Bajas de Bolivia. Memorias del I Congreso de Arqueología de Bolivia, editado por C. Rivera, pp. 3-12. Instituto de Investigaciones Antropológicas y Arqueológicas, Universidad Mayor de San Andrés, La Paz.

Hastorf, C.A. 2008b. The formative period in the Titicaca basin. En Handbook pf South American Archaeology, editado por H. Silverman y W.H. Isbell, pp. 545-561. Springer, Nueva York.

Hastorf, C.A., M. Bandy, W. T. Whitehead y L. Steadman 2001. El periodo Formativo en Bolivia: Regiones y Sociedad. Textos Antropológicos 13:17-91.

Hedges, R.E.M., R.A. Housley, I.A. Law y C. Bronk-Ramsey 1989. Radiocarbon dates from the Oxford AMS System: Archaeometry datelist 9. Archaeometry 31:225-234.

Hogg, A G., Q. Hua, P. Blackwell, M. Niu, C. Buck, T. Guilderson, T. Heaton, J. Palmer, P. Reimer, R. Reimer, C. Turney y S. Zimmerman 2013. SHCal13 Southern Hemisphere Calibration, 0-50,000 Years cal BP. Radiocarbon 55:1889-1903.

Holden, T.G. 1991. Evidence of prehistoric diet from Northern Chile: Coprolites, gut contents and flotation samples from the Tulán quebrada. World Archaeology 22:320-331.

Ikehara, H. y K. Shibata 2005. Festines e integración social en el periodo formativo: nuevas evidencias de Cerro Blanco, valle bajo de Nepeña. Boletín de Arqueología PUCP 9:123-159.

Kalazich, F. 2006. Tipología y contextos de uso de la alfarería temprana de Tulán y puna de Atacama. Informe de Práctica Profesional, Departamento de Antropología, Facultad de Ciencias Sociales, Universidad de Chile, Santiago. Manuscrito en poder de la autora.

Labarca, R. 2005. Zooarqueología de Fauna Menor en la Puna Salada: El Caso de Quebrada Tulán (II Región, Chile). Tesis para optar al título de Arqueólogo, Departamento de Antropología, Universidad de Chile, Santiago.

Lanting, J.N. y J. Van Der Plicht 1998. Reservoir Effects and Apparent 14C Ages. The Journal of Irish Archaeology 9:151-165.

Llagostera, A. 2015. Albores del psicotropismo en San Pedro de Atacama. Pipas vs. tabletas. Chungara Revista de Antropología Chilena 47:489-505.
López, P. 2010. Isótopos Estables en Restos de Camélidos de Quebrada Tulán (II Región-Chile): Uso del Espacio durante el Formativo Temprano (ca. 3.100-2.400 A.P.). Tesis para obtener el grado de Magíster en Antropología, Universidad Católica del Norte-Universidad de Tarapacá, San Pedro de Atacama.

López, P., I. Cartajena y L. Núñez 2013. Análisis de isótopos estables en colágeno de huesos de camélidos de Quebrada Tulán, puna de Atacama, periodo Formativo Temprano (ca. 3.100-2.400 a.p.). Chungara Revista de Antropología Chilena 45:237-247.

López Campeny, S. y P. Escola 2007. Un verde horizonte en el desierto: Producción de cuentas de minerales en ámbitos domésticos de sitios agropastoriales. Antofagasta de la Sierra (Puna Meridional Argentina). En Producción y Circulación Prehispánicas de Bienes en el Sur Andino, compilado por A. Nielsen, M. Rivolta, V. Seldes, M. Vásquez y P. Mercolli, pp. 225-257. Editorial Brujas, Córdoba.

Makowski, K. 2005. La religión de las altas culturas de la costa del Perú prehispánico. En Religiones Andinas, editado por M.M. Marzal, pp. 39-88. Editorial Trotta, Madrid.

Marzal, M. 1983. Transformación religiosa peruana. Pontificia Universidad Católica del Perú, Fondo Editorial, Lima.

McAndrews, T.L. 2005. Los sistemas de asentamientos Wankarani desde una perspectiva evolutiva. Estudios de una sociedad temprana basada en la aldea y su evolución cultural en el sur del altiplano central andino. Memoirs in Latin American Archaeology 15. University of Pitsburgh, Pitsburgh.

McRostie, V. 2014. Arboricultura y silvopastoralismo en el Período Formativo (1.400 a.C.-500 d.C.) de la cuenca del salar de Atacama. Chungara Revista de Antropología Chilena 46:543-557.

Meighan, C.W. 1980. Archaeology of Guatacondo. En Prehistoric Trails of Atacama: Archaeology of Northern Chile, editado por C.W. Meighan y A.L. True. Monumenta Archaeologica 7, pp. 99-126. The Institute of Archaeology, The University of California, Los Angeles.

Núñez, L. 1964. Tallas Prehispánicas en Madera. Contribución a la Arqueología del Norte de Chile. Tesis para obtener el título de Profesor de Historia y Geografía, Instituto Pedagógico, Universidad de Chile, Santiago.

Núñez, L. 1992. Emergencia de complejidad y arquitectura jerarquizada en la Puna de Atacama: evidencias del sitio Tulán-54. En Taller de Costa a Selva, editado por M.E. Albeck, pp. 85-115. Instituto Interdisciplinario de Tilcara, Jujuy.

Núñez, L. 2006. Asentamientos formativos complejos en el centro sur andino: cuando la periferia se constituye en núcleo. Boletín de Arqueología PUCP 10:321-356.

Núñez, L., M. Grosjean e I. Cartajena 1999. Un ecorefugio oportunístico en la puna de Atacama durante eventos áridos del Holoceno Medio. Estudios Atacameños 17:125-174.

Núñez, L., C. Agüero, B. Cases y P. De Souza 2003. El campamento minero Chuquicamata-2 y la explotación cuprífera prehispánica en el Desierto de Atacama. Estudios Atacameños 25:7-34.

Núñez, L., I. Cartajena, C. Carrasco y P. De Souza 2006. El templete de Tulán de la puna de Atacama: Emergencia de complejidad ritual durante el Formativo Temprano (Norte de Chile). Latin American Antiquity 17:445-473. 
Núñez, L., I. Cartajena, C. Carrasco, P. De Souza y M. Grosjean 2006a. Emergencia de comunidades pastoralistas formativas en el sureste de la Puna de Atacama. Estudios Atacameños 32:93-117.

Núñez, L., I. Cartajena, C. Carrasco, P. De Souza y M. Grosjean 2006b. Patrones, cronología y distribución del arte rupestre arcaico tardío y formativo temprano en la cuenca de Atacama. En Tramas en la piedra. Producción y usos del arte rupestre, editado por D. Fiore y M M. Podestá, pp. 191-204. World Archaeology Congress, Sociedad Argentina de Antropología, Asociación de Amigos del Instituto Nacional de Antropología, Altuna Impresores, Buenos Aires.

Núñez, L., P. de Souza, I. Cartajena y C. Carrasco 2007. Quebrada de Tulán: Evidencias de interacción circumpuneña durante el formativo temprano en el sureste de la cuenca de Atacama. En Producción y Circulación prehispánicas de Bienes en el Sur Andino, editado por A. Nielsen, M.C. Rivolta, V. Seldes, M.M. Vásquez y P.H. Mercolli, pp. 287-304. Colección Historia Social Precolombina, T. II, Editorial Brujas, Córdoba.

Núñez, L., V. McRostie e I. Cartajena 2009. Consideraciones sobre la recolección vegetal y la horticultura durante el formativo temprano en el sureste de la cuenca de Atacama. Darwiniana 47:56-75.

Núñez, L., I. Cartajena, P. de Souza y C. Carrasco 2009. Temprana arquitectura ceremonial en la Puna de Atacama (Norte de Chile). Andes 7:459-490.

Núñez, L. y C. Santoro 2011. El tránsito arcaico-formativo en la Circunpuna y Valles occidentales del Centro Sur Andino: Hacia los cambios "neolíticos". Chungara Revista de Antropología Chilena 43:487-530.

Núñez, M. 2011. Rutas, viajes y convidos: territorialidad peineña en las cuencas de Atacama y Punta Negra. En En Ruta. Arqueología, Historia y Etnografía del Tráfico Sur Andino, editado por L. Núñez y A. Nielsen, pp. 373-398. Editorial Brujas, Córdoba.

Núñez, L., I. Cartajena y C. Carrasco 2011. Aldeas formativas tempranas de la quebrada Tulán: su naturaleza, articulación y disolución en el escenario Circumpuneño y Centro Sur Andino (1200-400 A.C.). Informe final Proyecto Fondecyt 1070040. Manuscrito en poder de los autores.

Núñez, L., I. Cartajena, C. Carrasco y P. De Souza 2011. Estudio de colecciones con dataciones sincrónicas relacionadas con la fase Tilocalar (3130 a 2380 A.P.) a través de indicadores comparativos. Informe final Proyecto Fondecyt 1070040. Manuscrito en poder de los autores.

Pollard, G. 1970. The Cultural Ecology of Ceramic Stage Settlement in the Atacama Desert. Ph.D. Dissertation. Department of Anthropology, Columbia University, New York.

Ponce, C. 1970. Wankarani y Chiripa y su Relación con Tiwanaku. Academia Nacional de Ciencias 25, La Paz.

Rees, Ch. 1999. Elaboración, distribución y consumo de cuentas de malaquita durante el formativo en la vega de Turi y sus inmediaciones, subregión del río Salado, norte de Chile. En Los Tres Reinos: Prácticas de Recolección en el Cono Sur de América, editado por C. Aschero, M.A. Korstanje y P.M. Vuote, pp. 83-94. Instituto de Arqueología y Museo, Universidad Nacional de Tucumán, Tucumán.

Rees, Ch. y P. De Souza 2004. Producción lítica durante el periodo formativo en la subregión del río Salado. Chungara Revista de Antropología Chilena Volumen especial, Tomo I:453-465.
Roddick, A.P. 2002. Archaeological approaches to Ritual in the Andes: A Ceramic Analysis of Ceremonial Space at the Formative Period Site of Chiripa, Bolivia. Master Thesis, University of British Columbia, Vancouver.

Roddick, A.P. 2008. Aproximaciones arqueológicas al ritual en los Andes: Un análisis del espacio ritual durante el periodo formativo medio en el sitio Chiripa, Bolivia. En Arqueología de las Tierras Altas, Valles Interandinos y Tierras Bajas de Bolivia. Memorias del I Congreso de Arqueología de Bolivia, editado por C. Rivera, pp. 13-26. Instituto de Investigaciones Antropológicas y Arqueológicas, Universidad Mayor de San Andrés, La Paz.

Rodríguez, M.F. 2005. Identificación de restos vegetales del sitio Tulán-52. Informe de avance, Proyecto Fondecyt 1020316. Manuscrito en poder del autor.

Román A. 2011. Datación de cerámicas del sitio quebrada de Tulán. Informe, Pontificia Universidad Católica de Chile. Facultad de Física, Laboratorio de Dosimetría, Santiago de Chile. Manuscrito en poder del autor.

Rose, C.E. 2001. Organización residencial en una aldea del Período Formativo Temprano: el sitio Wankarani de La Barca, Oruro. Textos Antropológicos 13:147-165.

Rösing, I. 1994. La deuda de ofrenda: Un concepto central de la religión andina. Revista Andina 12:191-215.

Santander, B. 2009. Modelos Secuenciales para Tecnología Ósea durante la Transición Arcaico-Formativo en Atacama, el caso de la Quebrada Tulán. En Zooarqueología y Tafonomía en el Confín del Mundo, editado por P. López, I. Cartajena, C. García, F. Mena, pp. 45-58. Universidad Internacional Sek, Santiago.

Santander, B. 2014. Bone tools use-wear in an Early Formative pastoralist Site of Northern Chile: Weaving and piercing at the dawn of herds. En International Conference on Use-Wear Analisys. Use-Wear 2012, editado por J. Marreiros, N. Bicho, J. Guibaja Bao, pp. 551-560. Cambridge Scholars Publishing, Newcastle.

Sinclaire, C., M. Uribe, P. Ayala y J. González 1998. La alfarería del período formativo en la región del Loa superior: Sistematización y tipología. Actas del XIV Congreso Nacional de Arqueología Chilena, vol. 2, pp. 285-314. Copiapó.

Soto, C. 2009. Trabajo del mineral de cobre en Quebrada Tulán, Norte de Chile. La producción de objetos perforados en Tulán 85. Informe Proyecto FONDECYT 1070040. Manuscrito en poder de la autora.

Soto, C. 2010. Objetos perforados en Tu-54: tipología y distribución. Informe del proyecto FONDECYT 1070040. Manuscrito en poder de la autora.

Stanish, Ch. 2003. Ancient Titicaca. The Evolution of Complex Society in Southern Peru and Northern Bolivia. University of California Press, Berkeley.

Steadman, L. 2002. The Yaya-Mama religious tradition of Chiripa. Ponencia presentada en el 67th Annual Meeting of the Society for American Archaeology, Denver.

Tarragó, M. 1989. Contribución al Conocimiento Arqueológico de las Poblaciones de los Oasis de San Pedro de Atacama en Relación con los Otros Pueblos Puneños, en Especial el Sector Septentrional del valle Calchaquí. Tesis para optar al grado de Doctor, Universidad Nacional de Rosario, Rosario. 
Thomas, C., A. Benavente, I. Cartajena y G. Serracino 1995. Topater un cementerio temprano; una aproximación simbólica. Hombre y Desierto 9:159-170.

Uribe, M. 2004. La cerámica arqueológica del sitio Tulán-54: análisis tipológico y depositacional de un sitio formativo temprano del salar de Atacama. Informe de avance, Proyecto Fondecyt 1020316. Manuscrito en poder del autor.

Uribe, M. 2006. Sobre cerámica, su origen y complejidad social en los Andes del desierto de Atacama. En Esferas de Interacción Prehistóricas y Fronteras Nacionales Modernas: Los Andes Sur Centrales, editado por H. Lechtman, pp. 449-502. Instituto de Estudios Peruanos, Lima.
Varela, V. 2011. Análisis de seis fragmentos cerámicos Tulán54, quebrada de Tulán, puna de Atacama. Informe proyecto FONDECYT 1070040. Manuscrito en poder de la autora.

Ventura, B. 1999. Arqueología de los Valles Orientales a las Serranías de Zenta y Santa Victoria, Salta. Tesis para optar al grado de Doctor en Filosofía y Letras, Facultad de Filosofía y Letras, Universidad de Buenos Aires, Buenos Aires.

Walter, R. 1966. Beitrage zur Archaologie Boliviens. Die Grabungen des Museums fur Volkerkunde Berlin im Jahre 1958. Archaologische in Kordilleren Boliviens II, Verlag von Dietrich Reimer, Berlin. 
